\title{
COMPARING IMPEACHMENT REGIMES
}

\author{
JOHN OHNESORGE*
}

Impeachment, whether of presidents, judges, or other government officials, is increasingly common in political systems around the world, most importantly in presidential systems, where it can be used to remove heads of state who otherwise serve fixed terms. Despite this existence of a common and important legal tool in many jurisdictions, comparative scholarship on impeachment is rare, especially by legal scholars. This article responds to that scarcity by offering a methodological approach upon which future comparative impeachment scholarship can draw. The approach addresses many of the legal and political issues that impeachment raises, and incorporates insights from both law and political science, based on a belief that impeachment cannot be fully understood through either a purely legal or purely political lens. In order to construct this approach, this article draws on characteristics of the impeachment regimes of the United States and the Republic of Korea, which differ along several important dimensions and can thus be used to highlight different approaches to common issues. The goal is to demonstrate the value of comparative impeachment scholarship to those who seek to understand impeachment more deeply, whether as scholars or as citizens.

I. INTRODUCTION 260

II. APPROACHES TO COMPARATIVE IMPEACHMENT SCHOLARSHIP. 267

III. COMPARING IMPEACHMENT REGIMES 270

A. Impeachment Regimes not Impeachment Law ................................ 270

B. Evaluating Impeachment Regimes: Over and Under Inclusiveness, or Not-Too-Much-Not-Too-Little Goods.... 272

Copyright (C) 2021 John Ohnesorge

* George Young Bascom Professor of Business Law, University of Wisconsin Law School. I would like to thank Seoul National University and the Seoul National University School of Law for the very generous support I received through the SNU Global Scholar Visiting Researcher Program, which made my Fall, 2017 research visit possible. I would also like to thank the SNU faculty for their warm welcome and helpful feedback on my research, as well as the participants in the American Society of Comparative Law's Fourteenth Annual Works-in-Progress Workshop, hosted by the University of Illinois College of Law, especially Dean Vikram Amar and Professor Tim Sellers. Finally, I would like to thank the students and faculty of Kenyon College's Center for the Study of American Democracy, who heard a version of this paper, participants in the University of Wisconsin Law School's Wednesday Workshop series, and Sun Young (Sunny) Cho and Luis Carreno for their valuable research assistance. 
IV. COMPARING IMPEACHMENT CONTEXTS......................................... 276

A. Who Can Be Impeached? ............................................................ 276

B. Impeachment in Relation to the Criminal and Civil Justice

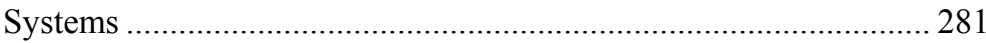

C. Impeachment for Official vs. Non-Official Conduct....................... 285

D. Consequences of Impeachment .................................................... 287

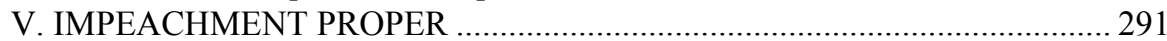

A. Impeachment Standards ............................................................ 291

B. Voting Requirements: Quorum and Voting .................................. 292

C. Structuring Impeachment Through Precedent ................................. 295

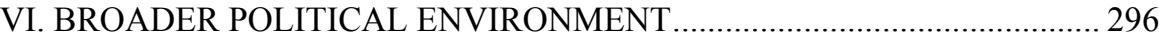

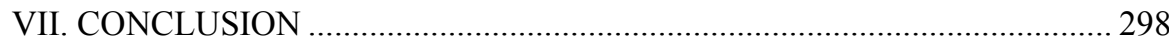

\section{INTRODUCTION}

The United States Constitution does not guarantee four-year terms for American presidents. Presidents serve for four years or until removed from office through impeachment. ${ }^{1}$ Likewise, American federal judges do not enjoy lifetime appointments under the Constitution; they hold office as long as they wish or until removed through impeachment or conviction. ${ }^{2}$ Although no one would dispute the accuracy of these statements, they do not reflect the way Americans commonly talk about the tenures of presidents or federal judges because impeachment in the United States is so rare. ${ }^{3}$ In the entire history of the United States, the House of Representatives has

1. Impeachment is typically a two-stage process. Charlie Savage, How the Impeachment Process Works, N.Y. TIMES (Feb. 9, 2021), https://www.nytimes.com/2019/09/24/us/politics/impeachmenttrump-explained.html [https://perma.cc/BH7W-2QSU]. Generally, a legislative body first adopts a bill of impeachment that functions like an indictment against the accused official, which is then adjudicated by a second body. Id. In this essay "impeachment" will be used to refer to the action of the first body, whether or not the process ultimately results in a conviction and sanction by the adjudicating body. Thus, for example, U.S. presidents Andrew Johnson, Bill Clinton and Donald Trump were impeached by the House of Representatives, though not convicted by the Senate. See id. Additionally, U.S. presidents can also be removed pursuant to Section 4 of the 25th Amendment, though that has never been used. Miles Parks, What the 25th Amendment Says About Removing a Sitting President, NPR (Jan. 7, 2021, 2:15 PM), https://www.npr.org/sections/insurrection-at-the-capitol/2021/01/07/919400859/what-happens-if-thepresident-is-incapacitated-the-25th-amendment-charts-a-cours [https://perma.cc/V3MQ-P66W] ("It's become a frequent topic throughout the Trump presidency, but the 25th Amendment has never actually been used before to take powers away from a president without his consent.").

2. U.S. CONST. art. III, $\S 1$ ("The Judges, both of the supreme and inferior Courts, shall hold their Offices during good Behaviour....").

3. See, e.g., Branches of the U.S. Government, USAGov (Jan. 21, 2021), https://www.usa.gov/ branches-of-government\#item-214500 [https://perma.cc/JC6F-4CYK] (last visited Mar. 27, 2021) ("The president leads the country. He or she is the head of state, leader of the federal government, and Commander in Chief of the United States armed forces. The president serves a four-year term and can be elected no more than two times."). 
impeached twenty officials - only eight of whom have been convicted and removed by the Senate. ${ }^{4}$ Impeachment is infrequent in the U.S. because the applicable rules governing impeachment, found primarily in the Constitution but also in the rules of the houses of Congress, intentionally function together with our political structures and culture to make it so.

The word "infrequent," an inherently relative term, invites comparison. Americans may feel that presidential impeachments are rare, but other countries with presidential systems also have impeachment mechanisms, and perhaps they use them even less frequently. ${ }^{5}$ That could be because their rules are more restrictive, or perhaps because of how their political institutions work. Other societies might also resort to presidential impeachment more often. So often, perhaps, that the possibility of impeachment would become part of the way to think about presidential terms. Would such frequent resort to presidential impeachment be a good thing, for the "shotgun behind the door" to be so close at hand, or would that destabilize a political system premised upon significantly insulating the executive branch from the legislative, as presidential systems are? he answer may depend upon what other alternatives to impeachment are available. If military coups are a real possibility, as has been true in many countries, an increased use of impeachment may be a healthy development. ${ }^{6}$ Whether frequently or infrequently used, however, impeachment is an important

4. See List of Individuals Impeached by the House of Representatives, HISTORY, ART \& ARCHIVES: U.S. HOUSE REPRESENTATIVES [hereinafter List of Individuals Impeached], https://history.house.gov/Institution/Impeachment/Impeachment-List/ [https://perma.cc/659K-QHDV] (last visited Mar. 24, 2021). In addition to the eight convicted and removed by the Senate, some officials that were subjected to impeachment inquiries chose to resign rather than contest the process to the end, including President Richard Nixon. Nixon Resigns, History (Aug. 5, 2020), https://www.history.com/this-day-in-history/nixon-resigns [https://perma.cc/UV2U-VB6R].

5. There is a vast literature comparing and contrasting parliamentary, presidential, and semipresidential political systems. See, e.g., José Antonio Cheibub et al., Beyond Presidentialism and Parliamentarism, 44 BRITISH J. POL. SCI. 515 (2014) (investigating whether the defining characteristics that distinguish presidential and parliamentary constitutions predict other attributes that are stereotypically associated with these institutional models). For purposes of this essay, the important difference between presidential and parliamentary systems is that in the former the president, the head of the executive branch, is significantly independent from the legislature because he or she is directly elected for a fixed term. $I d$. at 518-19. This desire was famously reflected in James Madison's objection, during the drafting of the U.S. Constitution, to the inclusion of "maladministration" as a ground for impeachment, which he felt would leave the President too vulnerable to removal by the House and Senate. See Jared P. Cole \& Todd Garvey, CONG. RsCH. SERV., R46013, IMPEACHMENT AND THE CONSTITUTION 1, 7 (2019). For a brief and timely comparison of presidential and parliamentary systems in holding chief executives accountable, see Grant Havers, Parliament or Congress: Which System Better Holds Executives Accountable?, LAW \& LIBERTY (Jan. 30, 2020), https://www.lawliberty.org/2020/01/ 30/parliament-or-congress-which-system-better-holds-executives-accountable/ [https://perma.cc/4NG3LRB9].

6. See infra notes 166-67 and accompanying text. 
institution of presidential democracies, a safety valve to remove individual leaders without threating democratic regimes themselves.

And what about judges and executive branch officials other than heads of state? The reasons for insulating judges from the legislature may differ from the reasons for insulating presidents and the executive branch, but should impeachment be used less often against judges, or more? ${ }^{7}$ If impeachment should be used differently against judges, should the formal requirements differ, or is it preferable to have a common set of rules and to trust that the politicians operating the impeachment process will calibrate it appropriately? ${ }^{8}$ Finally, what about executive branch officials below the President? The U.S. Constitution allows impeachment of "all civil Officers of the United States," and while the exact scope of "civil Officers" is debated, ${ }^{10}$ impeachment clearly extends beyond the President. Despite occasional threats, impeachment has almost never been used against lower executive branch officials in the U.S.. ${ }^{11}$ Should that change, and if so, how would that affect the balance of power between the executive and legislative branches, especially if presidential impeachments remained rare? Every political system that employs impeachment has to face such questions because deciding how impeachment should be structured, legally and politically, depends upon normative judgments about how impeachment should function. ${ }^{12}$ Those judgments are ultimately for the citizens of each

7. Concerns about individual due process in adjudications are a primary difference between the impeachment processes for judges versus presidents, but not the only ones. A judiciary free from legislative branch control is also crucial for enforcing constitutional checks and balances.

8. Under the U.S. Constitution the rules are not the same, as federal judges "hold their Offices during good Behaviour," but the import of the differences is a matter of debate. U.S. CONST. art. III, $\S 1$; see infra note 73 .

9. U.S. CONST. art. II, §4.

10. For an analysis of officer status in a related context, see generally Officers of the United States Within the Meaning of the Appointments Clause, 31 Op. O.L.C. 73-74 (2007) [hereinafter O.L.C., Officers of the United States] (concluding that under the Appointments Clause, a position is a federal office "if (1) it is invested by legal authority with a portion of the sovereign powers of the federal government, and (2) it is 'continuing"').

11. See generally David E. KyVig, The Age of IMPEACHMENT: AMERICAN CONSTITUTIONAL CULTURE SinCE 1960, at 30 (2008) (describing the impeachment and Senate acquittal of Secretary of War William W. Belknap). On threats to impeach executive branch officials, see, e.g., Justin Wise, Warren Renews Call for Barr to Resign over Roger Stone Sentencing, HILl (Feb. 12, 2020, 12:43 PM), https://thehill.com/homenews/senate/482764-warren-renews-call-for-barr-to-resign [https://perma.cc/ 3NB2-PMMC]; George F. Will, Opinion, Congress Should Impeach the IRS Commissioner-or Risk Becoming Obsolete, WASH. POST (Sept. 9, 2016), https://www.washingtonpost.com/opinions/congressshould-impeach-the-irs-commissioner-or-risk-becoming-obsolete/2016/09/09/bae91306-75ee-11e68149-b8d05321db62_story.html [https://perma.cc/2XET-HAZF].

12. Although impeachment is usually discussed at the national level, in federal systems it may exist at the state or local levels as well. For example, U.S. state constitutions contain impeachment mechanisms, and some contain citizen recall mechanisms as well. See Recall of State Officials, NAT'L 
country to make, but their decisions do not need to be made in isolation. Although unique, political systems share enough in common to make comparative study useful, especially when considering something as rare but impactful as impeachment.

In Judge Richard Posner's retrospective on the effort to impeach U.S. President Bill Clinton, he noted the rarity of comparative studies on impeachment, despite the fact that the mechanism exists in many legal systems. ${ }^{13}$ In the nearly two decades since Judge Posner's book appeared, there have been presidential impeachments in several of the world's democracies, large and small. ${ }^{14}$ Of particular interest, South Korean

CONF. ST. LeGiSLATURES (July 8, 2019), http://www.ncsl.org/research/elections-and-campaigns/recallof-state-officials.aspx [https://perma.cc/2TWL-Z5P6]. Recall votes, unlike impeachment, place removal under the direct control of the electorate, rather than requiring that removal be done through elected representatives, as in impeachment. Id. Many executive branch officials below the chief executive are appointed, not elected, but it isn't obvious that removing appointed officials through voter recall is a worse method than removing them through impeachment - the method adopted in the U.S. Constitution. Voter recall is not available against any U.S. government official, but even a quick look at how recall is used in American states provides interesting food for thought. For example, while many states limit recall to elected officials, typically governors or state legislators, others extend it to other state officials, including state judges in some cases. Id. At least one state, New Jersey, allows recall of its federal members of Congress. Id. Some states try to require that recall be based on wrongdoing, an attempt to constrain recall that would be similar to constraining impeachment by requiring an impeachable offense. $I d$. Other states do not require reasons for recall, thus seeming to endorse the idea that recall should be an entirely political process. Id. Another interesting state level practice is to allow both recall and impeachment, as is the case in Arizona. Id. In 1988, the opponents of Arizona Governor Evan Mecham had gathered enough signatures to trigger a recall vote, but the legislature impeached him before the recall was carried out. Id.

13. Richard A. Posner, An AfFair of State: The InVEStigation, IMPEACHMENT, AND Trial OF PRESIDENT CLINTON 100 n.20 (1999) (“American students of impeachment are provincial; they do not study the foreign experience.").

14. For example, Philippine President Joseph Estrada was targeted with impeachment in 2000, and though ultimately not convicted, he resigned from office after the Chief Justice of the Philippine Supreme Court preemptively swore in his vice president as president. Yuko Kasuya, Weak Institutions and Strong Movements: The Case of President Estrada's Impeachment and Removal in the Philippines, in CHECKING Executive power: Presidential Impeachment in Comparative Perspective 45 (Jody C. Baumgartner \& Naoko Kada eds., 2003). In 2012, Fernando Lugo was successfully impeached and removed as the president of Paraguay. Leiv Marsteintredet et al., Paraguay and the Politics of Impeachment, 24 J. DEMOCRACY 110, 111 (2013). President Lugo was the second president of Paraguay to have his term "interrupted" by that process. See Arturo Valenzuela, Latin American Presidencies Interrupted, 15 J. DEMOCRACY 5, 8 (2004) (noting that the first president of Paraguay to be interrupted was Raúl Cubas). Brazil's President Dilma Rousseff was removed from office after impeachment and conviction in 2016. Simon Romero, Dilma Rousseff Is Ousted as Brazil's President in Impeachment Vote, N.Y. TIMES (Aug. 31, 2016), https://www.nytimes.com/2016/09/01/world/americas/brazil-dilmarousseff-impeached-removed-president.html [https://perma.cc/G59H-TWVZ]. She was the second Brazilian president, after Fernando Collor de Mello, to be removed via impeachment under Brazil's present constitution. Naoko Kada, Impeachment as a Punishment for Corruption? The Cases of Brazil and Venezuela, in Checking EXecutive Power: Presidential Impeachment in Comparative PERSPECTIVE, supra note 14, at 113. Attempts were also made to impeach Brazilian presidents Fernando Henrique Cardoso and Luís Inácio Lula da Silva, though all ultimately failed. Rodrigo Zeidan, 
President Noh, Moo-hyun was impeached in 2004. Although the Korean Constitutional Court decided against removing him from office, Noh later chose to resign. ${ }^{15}$ South Korea experienced another impeachment in 2016 when President Park, Gun-hye was impeached by Korea's National Assembly. ${ }^{16}$ Unlike President Noh, her removal was ordered by the Korean Constitutional Court. ${ }^{17}$

Despite regular use of impeachment to challenge presidents around the world - to say nothing of impeachment efforts against judges and other government officials-Judge Posner's observation remains largely accurate. ${ }^{18}$ Impeachment - by any measure, a drastic step in a democracyis not actually that rare, yet it is rarely studied comparatively, especially by legal academics. Moreover, what legal academics have written about impeachment in jurisdictions other than their own is not necessarily comparative, or may contain just casual comparative observations. ${ }^{19}$ Political

Impeachment and the New Democracy in Brazil, PragmatiC ECON. \& SustainABle Fin. (Apr. 16, 2016), https://rzeidan.com/2016/04/16/impeachment-and-the-new-democracy-in-brazil/ [https://perma. cc/UKP8-5EHM]. More recently, political opponents of Philippine President Duterte introduced an impeachment bill in the lower house of the Philippine legislature. Felipe Villamor, Philippines Kills Impeachment Complaint Against Rodrigo Duterte, N.Y. TIMES (May 15, 2017), https://www.nytimes.com/2017/05/15/world/asia/rodrigo-duterte-philippines-impeachment.html [https:/ /perma.cc/PP3X-TVF6]. President Kuczynski of Peru resigned in the face of a second impeachment attempt, having narrowly survived the first. Ryan Dube, Peru's President Pedro Pablo Kuczynski Resigns, WALL ST. J. (Mar. 21, 2018, 7:02 PM), https://www.wsj.com/articles/perus-president-pedropablo-kuczynski-resigns-1521661203 [https://perma.cc/3DNV-ZBA6].

15. John Ohnesorge, Impeachments Compared: Presidents Roh and Clinton in Law and Politics, in Situating Korean Studies in a Global and Multi-Disciplinary CONTEXT: ProceEdings For 2ND INTERNATIONAL ForUM ON KOREAN STUDIES (2006); Youngjae Lee, Law, Politics, and Impeachment: The Impeachment of Roh Moo-hyun from a Comparative Constitutional Perspective, 53 AM. J. COMP. L. 403, 412 (2005); Hahm Chaihark, Professor, Yonsei Univ., Discussion at the Hills Governance Center at Yonsei's 2nd Symposium on Public Governance: Impeachment and the Korean Constitutional Order (Mar. 22, 2004).

16. Uk Heo \& Seongyi Yun, South Korea in 2017: Presidential Impeachment and Security Volatility, 58 ASIAN SURV. 65, 65 (2018); Hyun-Soo Lim, A Closer Look at the Korean Constitutional Court's Ruling on Park Geun-hye's Impeachment, YALE J. INT'L L. (May 18, 2017), https://www.yjil.yale.edu/a-closer-look-at-the-korean-constitutional-courts-ruling-on-park-geun-hyesimpeachment/ [https://perma.cc/KY9P-DM2A].

17. Heo \& Yun, supra note 16, at 65-66.

18. But see Tom Ginsburg et al., The Uses and Abuses of Presidential Impeachment, 88 U. CHI. L. REV. (forthcoming) (discussing, through a comparative analysis, how impeachment can be better understood as a tool through which political systems may reset their leadership by triggering new elections); Daniel H. Erskine, The Trial of Queen Caroline and the Impeachment of President Clinton: Law as a Weapon for Political Reform, 7 WASH. U. GLOB. STUD. L. REV. 1 (2008) (illustrating, through a comparative analysis, how the impeachment process has historically been used as a "political weapon .... to instigate political change ..."). Posner's observation was never true in one fundamental respect, as U.S. discussions of impeachment, from the Founding until today, generally assume that England's impeachment experience is relevant to our own. For an excellent introduction to English practice in relation to the U.S., see Editorial, 3 ANGLO-AM. L. REV. 285 (1974).

19. See, e.g., Laurence Tribe \& Joshua Matz, To End a Presidency: The Power of 
scientists have made greater efforts to systematically compare impeachment regimes, ${ }^{20}$ though they also often note the scarcity of such work. ${ }^{21}$ Symptomatic of this disregard, scholars at the core of the Comparative Constitutions Project, which applies sophisticated political science methods to the comparative study of constitutions, wrote in 2013 that, "governments in presidential systems do not risk removal from power in the middle of their term." 22 The authors were drawing a distinction between presidential and parliamentary systems, in which leaders of the executive branch are responsible to the legislature, but by ignoring the possibility of presidential impeachment they over-state the distinction. Presidents are being removed in the middle of their terms via impeachment, and the way impeachment works in a political system tells much about the actual independence of the president from the legislative branch. This in turn matters both for comparative politics scholarship and, perhaps more importantly, for citizens of presidential systems who wish to think more deeply about the possibilities and limits of their political orders.

This essay responds to the scattered state of comparative impeachment research by proposing a general framework to structure future scholarship, a framework constructed by identifying and exploring issues common to impeachment regimes. These issues are identified primarily through the study of two quite different impeachment regimes, those of the United States and South Korea (Korea). ${ }^{23}$ The list of issues discussed is not intended to be exhaustive, but the U.S. and Korean systems differ from one another in

IMPEACHMENT 26-27 (2018) (making casual reference to the approaches that some U.S. state constitutions, and some foreign constitutions, take when defining impeachable offenses, without citing a foreign authority). Youngjae Lee's excellent article about the impeachment of South Korean President Noh, is framed primarily as a case study, but contains thoughtful comparative observations, particularly with respect to the U.S. impeachment regime. See Lee, supra note 15.

20. See, e.g., Aníbal PÉrez-Liñán, Presidential ImPeachment and the New Political INSTABILITY IN LATIN AMERICA 38 (2007) (providing a table listing impeachment attempts in Latin America in the 1990s and early 2000s and their outcomes); Kasuya, supra note 14 (conducting a comparative analysis of the impeachment processes in the United States, the Philippines, Colombia, Madagascar, Russia, Brazil and Venezuela).

21. Jody C. Baumgartner, Introduction: Comparative Presidential Impeachment, in CHECKING EXeCUTIVE PoWer: PReSidential IMPEACHMENT In COMPARATIVE PERSPECTIVE, supra note 14, at 3.

22. Cheibub et al., supra note 5, at 519 (emphasis added). For more on the Comparative Constitutions Project, see Zachary Elkins et al., The Comparative Constitutions Project: A Cross-National Historical Dataset of Written Constitutions (July 22, 2008) (unpublished manuscript), available at https://comparativeconstitutionsproject.org/research-design-cataloging-the-contents-of-constitutions/ [https://perma.cc/JK24-9FD8].

23. For a helpful summary of the South Korean impeachment process, see Choe Sang-Hun, South Korea's Impeachment Process, Explained, N.Y. TIMES (Nov. 27, 2016) [hereinafter Sang-Hun, South Korea's Impeachment Process], https://www.nytimes.com/2016/11/27/world/asia/impeaching-southkorea-president.html [https://perma.cc/9D6N-4J8E]. 
several important ways, ${ }^{24}$ which makes the two countries useful in this framework-building exercise. ${ }^{25}$

A framework that compares scholarship on impeachment must pay attention to both comparative law and politics because impeachment is both a legal and political process. As will be shown, the black-letter law of impeachment matters, both the law that determines how impeachment fits within the larger governance system and the law that governs the impeachment process itself. Even if the black-letter law of impeachment were identical in Korea and the U.S., however, the countries' institutions would likely implement those rules differently, suggesting limits to the usefulness of a solely legal comparison. Focusing on implementation of the is always important in comparative research, but the fact that political bodies play central roles in implementing impeachment law gives impeachment as practiced an irreducibly political element. Studying rules, structures and processes cannot fully capture what impeachment means for a society, ${ }^{26}$ or answer normative questions such as how frequent impeachment should be. What impeachment ultimately means for a society, however, and whether the system requires changing, is inextricably linked to the law, the practice, and the politics of impeachment.

Studying impeachment comparatively will deepen our understanding of constitutional law and practice around the world, and provide material to

24. Specifically, the U.S. is the world's oldest democracy characterized by having the following traits: a purely presidential system, an old constitutional text, a stable two-party system in which the parties regularly alternate in holding the presidency and the two houses of the legislature, a common law heritage, a powerful judiciary enforcing separate powers, and a system of checks and balances among the three branches. Korea, on the other hand, is a comparatively new democracy that is characterized as: having grown out of non-communist authoritarianism, being fundamentally presidential but having a prime minister, having a modern German-influenced constitution, a fractious and constantly changing party structure, a civil law system, and a Constitutional Court — in addition to a Supreme Court — that has become noteworthy for its assertiveness and is tasked with adjudicating impeachments in South Korea's system. Lee, supra note 15, at 406-08; Lim Jibong, The Korean Constitutional Court, Judicial Activism, and Social Change, in Legal ReForm In Korea 19 (Tom Ginsburg ed., 2004); TOM GinSBuRG, JUDICIAL REVIEW IN NEW DEMOCRACIES: CONSTITUTIONAL COURTS IN ASIAN CASES 206-46 (2003).

25. This study thus differs from more traditional comparative projects, which often draw on one system to provide lessons for the other. See, e.g., John Yoo, The Influence of the States in Constitutional Change: A Comparison of American and Korean Approaches to Constitutional Amendment, $18 \mathrm{~J}$. KOREAN L. 157 (2018).

26. Meaning refers here to how an impeachment is understood in the public consciousness of a society. Meaning can vary in magnitude, and meaning can also be contested. Thinking of meaning in this way, the impeachment and removal of a trial judge caught accepting bribes is likely to be of low and uncontested meaning. There are many trial judges, and few citizens are likely to believe that judges who accept bribes belong on the bench. The impeachment and acquittal of President Clinton, on the other hand, was arguably both highly meaningful and highly contested. For essays exploring the meaning of the Clinton impeachment, see AfTERMATH: THE Clinton IMPEACHMENT AND THE PRESIDENCY IN THE Age OF Political SpeCtacle (Leonard V. Kaplan \& Beverly I. Moran eds., 2001) [hereinafter Kaplan \& Moran]. 
those who want to think more deeply about impeachment in their societies. A way to study impeachment comparatively that will facilitate attention to both law and politics is through the comparison of impeachment regimes, consisting of substantive law, usually constitutional, procedural rules and practices, and political forces and institutions. Impeachment regimes can function in ways that are over or under-inclusive, providing too much or too little of the good for which they are created, so over and under-inclusion is a useful device for analyzing elements of such regimes. Because citizens ultimately evaluate their country's impeachment regime, the goal of the exercise should be to facilitate thoughtful analysis and critique, rather than provide answers.

This essay begins with an extended discussion of methodology, necessary given the novelty of the topic and the approach, followed by an application to the two countries examined. Section II discusses approaches to conducting comparative impeachment scholarship, identifying difficulties and possible objections, and then lays out the approach this essay ultimately adopts. Section III develops this framework for comparison, focusing first on the concept of impeachment regimes, then discussing the device of over and under-inclusion as a frame for analysis. Section IV discusses issues that help determine the place of impeachment within a society's larger constitutional order, while Section V addresses procedural and substantive legal standards of impeachment itself. Section VI addresses political structures and behavior to establish the context within which impeachment functions, while Section VII offers closing observations, as well as suggestions for future research.

\section{APPROACHES TO COMPARATIVE IMPEACHMENT SCHOLARSHIP}

Comparative law scholars have been admirably open about the methodological challenges the field faces. A comparative study of impeachment law and practice will certainly be open to challenge on various grounds. ${ }^{27}$ Rather than anticipating and responding to such challenges, this essay rejects several approaches, then introduces the approach that will be followed.

One framework to comparative impeachment research would be a doctrinal comparison of black-letter impeachment law across various countries. That approach would have the advantage of simplicity, allowing legal scholars to remain within their traditional domain, legal doctrine, and would contribute to the field because black-letter impeachment law does

27. See, e.g., Mathias Siems, Book Review, 65 AM. J. COMP. L. 462 (2017). 
matter for how impeachment functions. Such an approach will not be followed here for two reasons. First, even key doctrines such as the definition of an impeachable offense include irreducibly political elements because impeachment is administered, partially or wholly, by political bodies. Second, granting that useful insights could follow from the comparison of black-letter law, at present, when attention to the field has been so limited, a more holistic approach is called for. Although this essay will pay substantial attention to the legal rules governing impeachment, it will seek to build a framework that situates these within a broader political and social frame.

An attractive alternative to black-letter comparison would be to compare countries based on variations in their impeachment systems to measure the effects of such differences on non-legal metrics. ${ }^{28}$ One could easily imagine comparative impeachment scholarship looking at the difference between impeachment regimes, like Korea's, that utilize courts to adjudicate impeachments and those that use non-courts, typically upper houses in bicameral legislative systems such as the U.S. Such an approach could improve greatly over black-letter comparison by explicitly taking into account wider institutional contexts within which impeachment rules operate, and would also facilitate empirical research by allowing the use of large data sets. An obvious risk in that approach, however, would lie in applying common labels to institutions that are formally similar, but that might operate very differently in different societies, and also hold different socio-political meanings for the citizens of different societies. At this point, when so little comparative work on impeachment has been done, building a general framework on such a foundation should be done with care. It would be a mistake to go too far in the other direction, however, to focus so heavily on contextual details, social, political, historical, that the particularities of the individual impeachment regimes would overwhelm what they share in common. Such an anthropological approach would be important for elucidating the meaning of impeachment within a particular society, ${ }^{29}$ but unsuited to comparing different impeachment regimes.

Scholarly literature in the field of comparative politics contains more work on impeachment than comparative law, but that literature is also flawed. To their credit, the political scientists have begun the important task of developing models to facilitate comparison of impeachment across

28. The Comparative Constitutions Project is designed to facilitate this type of work. See Elkins et al., supra note 22 . For a recent study conducted relying on data collected by the Comparative Constitutions Project see, Joe Amick et al., On Constitutionalizing a Balanced Budget, 82 J. PoL. 1078 (2020).

29. See, e.g., Kaplan \& Moran, supra note 26. 
different political systems. ${ }^{30}$ Unfortunately, however, some of the scholars believe that if impeachment is a political phenomenon it cannot at the same time be a legal phenomenon. For example, Jody Baumgartner and Naoko Kada write that "[ $\mathrm{t}]$ he basic assumption of this book . . . is that impeachment is a political, rather than a legal proceeding. In other words, this book is about the politics of presidential impeachment." 31 A few pages later they write, "we take the position that presidential impeachment can only be understood as a political phenomenon." "32 The same stance is then adopted by other contributors to the volume as though it were an important commitment tying together their research. ${ }^{33}$ The stance is questionable, however, as even the contributors to that volume almost universally discuss legal issues in their chapters. ${ }^{34}$ That political scientists are unable to write a book about the politics of impeachment without covering a good deal of the law of impeachment shows why framing impeachment as being solely a legal or a political phenomenon is misguided. ${ }^{35}$ Impeachment is both political and legal, and just as understanding one country's experience with impeachment requires studying both its law and its political and social structures, a framework for comparing impeachment regimes must incorporate both legal and extra-legal factors. ${ }^{36}$

30. See, e.g., PÉREZ-LiÑÁN, supra note 20, at 132-75; Kada, supra note 14, at 137.

31. Baumgartner, supra note 21, at 2 (emphasis added).

32. Id. at 6 (emphasis added).

33. See, e.g., William B. Perkins, The Political Nature of Presidential Impeachment in the United States, in CHECKING EXECUTIVE POWER: PrEsidential IMPEACHMENT IN COMPARATIVE PeRsPeCtive, supra note 14 , at 21 .

34. Baumgartner identifies the "The Institutional Balance of Power," and the "Constitutional and Statutory Provisions for Impeachment" as the first two of five factors that condition presidential impeachments. Baumgartner, supra note 21, at 7-8. Both of these factors describe formal legal rules and structures.

35. For an example of the political-therefore-not-legal framing in the popular press, see, e.g., Andrew C. McCarthy, George Will's Call for Impeachment of the IRS Director, NAT'L REV. (Oct. 8, 2015, 2:11 PM), https://www.nationalreview.com/corner/george-wills-call-impeachment-irs-directorandrew-c-mccarthy/ [https://perma.cc/3KXP-6X5U] ("Impeachment . . is a political remedy, not a legal one ....") (emphasis in original).

36. In defense of the political scientists, they may be reacting to the tendency of legal academics to write about impeachment as if it were primarily a legal matter. It is unlikely that legal scholars believe that impeachment can be fully understood without serious attention to politics, yet they have a tradition of producing law-centric works on the subject. See, e.g., CASS R. SUNSTEIN, IMPEACHMENT: A CITIZEN'S GUIDE (2017). Other works taking largely legal approaches would include TRIBE \& MATZ, supra note 19; Charles L. Black, Jr., Impeachment: A Handbook (1974); Michael J. Gerhardt, The Federal ImPEACHMENT Process: A CONSTITUTIONAL AND Historical ANALYSIS (1996); RaOUL Berger, IMPEACHMENT: THE CONSTITUTIONAL PROBLEMS (enlarged ed. 1974). Like scholarship that focuses on the political aspects of impeachment, law-centric impeachment scholarship can be extremely valuable so long as its limitations are understood. For example, a classic topic of law-centric impeachment scholarship is the legal definition of an impeachable offense, which is an important undertaking because that definition will affect how the impeachment regime functions, even if it does not fully constrain the 
Given these limitations and concerns, this essay proposes an approach, encompassing both legal and non-legal factors, designed to help generate useful knowledge about impeachment as practiced around the world. Variations in impeachment regimes reflect choices, and bringing those choices to light will help evaluate the implications of those choices. The goal is to provide a framework to assist people - scholars, citizens, lawyers, politicians - in understanding impeachment across political systems so that they are better able to think about impeachment in their own societies. The stakes for political legitimacy are high because impeachment can address problems not easily addressed through other means. A single corrupt legislator will be only one vote in a collective body and can be replaced at the next election, but a corrupt or incompetent head of state could use influence over the executive branch and foreign affairs to inflict substantial harm on a society before the next election. The stakes are also high with respect to judicial impeachments, as corrupt or incompetent judges may threaten the integrity of their legal systems where impeachment is not available to overcome protections traditionally designed to ensure judicial independence.

\section{COMPARING IMPEACHMENT REGIMES}

Section III.A explains the comparison of impeachment regimes, defined to include both law and politics, while Section III.B suggests a metric across which impeachment regimes could be compared.

\section{A. Impeachment Regimes not Impeachment Law}

Although impeachment is like a criminal prosecution in that one body investigates and brings charges and a second body adjudicates based on facts and law, impeachment has a role for politics that the criminal process does not. This is not politics in the sense that a judge deciding a case arguably engages in politics when choosing between two possibly applicable rules, or crediting one version of the facts over another. ${ }^{37}$ Impeachment is irreducibly

bodies that apply the definition. We must assume that members of Congress who vote on impeachments will be interested in reelection, and that how they vote on an impeachment may be a salient issue the next time they face voters. Politicians' impeachment behavior will therefore take place in the shadow of the country's substantive legal standard, even if not governed fully by it. A related but more defensible framing is that impeachment is a political rather than a judicial process. See, e.g., Alan B. Morrison, Impeachment is a Political Process, Not a Judicial One, LAW.COM: NAT'L L. J. (Dec. 10, 2019, 12:46 PM), https://www.law.com/nationallawjournal/2019/12/10/impeachment-is-a-political-process-not-ajudicial-one/?slreturn=20210206145428 [https://perma.cc/74TP-8QLE]. Morrison's argument is that because judicial review of impeachment decisions is not available in the U.S., it is important not to see the impeachment process as a judicial one. $I d$. He is careful to note, however, that legal principles like due process still matter in impeachments, just not as grounds for judicial review. Id.

37. That sense of the political nature of judicial decision making has been associated with the 
political because political bodies perform one or both of these roles. It is a feature of impeachment that politicians, organized political parties, civil society groups, and individual citizens can mobilize for and against a potential impeachment. Understanding a nation's impeachment regime thus requires study of its laws and legal institutions, as well as its politics.

The political background of the 2020 President Trump impeachment proceedings and their subsequent fallout is emblematic of the fact that impeachments are rarely purely legal. As the 2020 presidential elections approach in the U.S., Republicans and Democrats must decide how to make best use of the reality that the Democrats' control of the House of Representatives allowed them to impeach President Trump, but that the Republicans' hold of the Senate allowed them to block his removal. ${ }^{38}$ Before the impeachment, House Speaker Nancy Pelosi and others downplayed impeachment to appeal to moderates, while other Democrats championed it to appeal to their own supporters. ${ }^{39}$ Cognizant that impeachment is partly a legal process, pro-impeachment Democrats in the House and Senate argued that Trump had committed impeachable "high crimes and misdemeanors," 40 whereas Republicans seeking to rally their supporters argued that he had not, and that the Democratic impeachment effort was thus an illegitimate effort to undo the 2016 presidential election. ${ }^{41}$ The 2020 elections will provide a vehicle for examining these processes, and while it might be a mistake to predict that many voters' judgements will be swayed by purely legal arguments, if the impeachment is an important issue in the election the debates will be carried out at least partly in the discourse of legality. This is one reason why law-centric impeachment scholarship is important. In addition, there are aspects of impeachment regimes, such as evidentiary standards or procedural rules, that shape how impeachment actions proceed, but are difficult for non-specialists to fully appreciate. Law-centric impeachment scholarship therefore has an important role to play in addressing certain types of issues.

indeterminacy theses of the American legal realism and critical legal studies movements. See, e.g., DUNCAN KENNEDY, A CRITIQUE OF ADJUDICATION (1997) (examining the effect of politics on judicial decision making and how law made by judges affects American politics).

38. Lindsay Wise, Post-Impeachment Senate Landscape Takes Shape, WALL ST. J. (Feb. 18, 2020, 5:30 AM), https://www.wsj.com/articles/post-impeachment-senate-landscape-takes-shape-11582021802 [https://perma.cc/8AJS-CDKZ].

39. Jonathan Martin, Republicans Seize on Impeachment for Edge in 2018 Midterms, N.Y. TIMES (Apr. 8, 2018), https://www.nytimes.com/2018/04/08/us/politics/trump-impeachment-midterms.html [https://perma.cc/KW7Q-3UGH].

40. See id. (quoting Representative Steve Cohen) ("I think he's committed impeachable offenses ....”).

41. Warren Davidson (@WarrenDavidson), TwitTer (Dec. 10, 2019, 3:19 PM), https://twitter.com/WarrenDavidson/status/1204495768826105857 [https://perma.cc/HH7V-JY6H]. 
A perennial challenge for those seeking to understand the U.S. impeachment regime is a lack of certainty about the rules of engagement, but the role of political bodies in the process builds in much of that uncertainty. The grounds of impeachment themselves, "other high crimes and misdemeanors," are highly indeterminate, but mechanisms that the AngloAmerican legal tradition typically relies upon to constrain textual indeterminacy, such as a significant history of past applications, applied in the case at hand by a trained judiciary displaying a substantial respect for precedent, do not exist in the U.S. impeachment context. ${ }^{42}$ As will be discussed more fully, ${ }^{43}$ there are simply too few past impeachments to provide guidance, but more fundamentally, while the members of the House and the Senate could decide for themselves to treat past cases as precedential in a judicial sense, or could perhaps treat leading scholarly interpretations or past English cases as persuasive authority, an institutional framework like the one that pressures judges to respect precedent and persuasive authority does not exist with respect to members of the House and the Senate.

\section{B. Evaluating Impeachment Regimes: Over and Under Inclusiveness, or Not-Too-Much-Not-Too-Little Goods}

Legal scholarship regularly employs over and under-inclusiveness as a device for discussing black-letter law, ${ }^{44}$ and legal doctrine incorporates the device as well. ${ }^{45}$ With certain adjustments, over and under inclusion can also be used as a device for comparing and evaluating impeachment regimes, considering both those regimes' black-letter law and their enforcement mechanisms. ${ }^{46}$ A similar approach using more familiar language is to understand impeachment as an example of what Laurence Lessig has called a "[n]ot-[t]oo-[m]uch-[b]ut-[n]ot-[t]oo-[1]ittle [g]ood[]." Wh Whether with respect to presidents, other officers, or judges, it is clear that the possibility of impeachment is important as a legitimate, peaceful way to remove bad

42. A potentially important issue that will not be addressed here is whether impeachment regimes in Common Law and Civil Law jurisdictions differ in their approach to precedent.

43. See infra Section V(C).

44. A rule is said to be over-inclusive if it is worded to capture conduct beyond what was intended, and under-inclusive if the opposite is true. See, e.g., Republican Party of Minn. v. White, 416 F.3d 738, 751 (8th Cir. 2005). For example, if the voting age is set at eighteen to ensure a mature electorate, that rule will be over-inclusive because it will exclude some mature citizens under eighteen from voting, but will also be under-inclusive for allowing some immature citizens over eighteen to vote.

45. See, e.g., Victory Processing, L.L.C. v. Fox, 937 F.3d 1218, 1228 (9th Cir. 2019) (finding that Montana's statute restricting robot calls violated the First Amendment for being both over-inclusive and under-inclusive).

46. The following discussion draws upon BLACK, JR., supra note 36, at 14-24.

47. Lawrence Lessig, Law Regulating Code Regulating Law, 35 LOY. U. CHI. L.J. 1, 2-3 (2003). 
actors, but it is equally clear how a resort to impeachment would sacrifice important values of the system.

The constitutional grounds for impeachment, for example, would be under-inclusive if they would not allow impeachment even if an official had committed serious misconduct, but would be considered over-inclusive if they allowed impeachment for even a trivial offense. ${ }^{48}$ An under-inclusion objection was in fact raised by Col. Mason during the American Constitutional Convention of 1787, when he argued that limiting the grounds for impeachment to treason and bribery would mean that the mechanism would "not reach many great and dangerous offences."49 Mason's suggestion for addressing the problem was to add "maladministration" as a third ground, to which Madison offered an over-inclusion objection, arguing that allowing impeachment for "maladministration" would give the Senate too much discretion to remove the President. ${ }^{50}$ The phrase "other high crimes and misdemeanors" was then included rather than "maladministration," and subsequent discussions of the scope of that phrase often employ the logic of over and under inclusion. ${ }^{51}$

The South Korean constitution provides an example of the same challenge, though it only allows impeachment upon proof of a violation of existing law. ${ }^{52}$ By itself, such a rule appears under-inclusive, as an official might commit acts deserving of impeachment that would not violate existing law. ${ }^{53}$ Grossly irresponsible personal behavior, or flagrant lying to the public with respect to matters of policy, would be examples. Korea's choice to tie impeachment to violations of law would also be over-inclusive if interpreted to allow impeachment for any violation of law, no matter how trivial.

48. It is important to recognize that deciding what is over- or under-inclusive depends on substantive judgments concerning issues, such as the wrongfulness of conduct and the effect of an impeachment on society.

49. The exchange is reproduced in BLACK, JR., supra note 36, at 28.

50. Id.

51. See, e.g., id. at 33-36. Black's suggestion for dealing with the potential over- and underinclusiveness of "high crimes and misdemeanors" was to apply the interpretative canon ejusdem generis, cabining the scope of that phrase by linking its interpretation to the specific grounds of treason and bribery which it follows. Id. at 36-41. He did not address the likelihood that the members of the House and the Senate would apply that or any other interpretive canon in their impeachment decisions. Id.

52. See DAEHANMINKUK HUNBEOB [HunBeOB] [CONSTITUTION] art. 65(1) (S. Kor.) (requiring a finding of a violation of "the Constitution or other laws in the performance of official duties," in order for a motion to be passed for impeachment).

53. Black explored the possibility of interpreting "high crimes and misdemeanors" to include only violations of law - achieving through interpretation what South Koreans wrote in their constitution - and concluded that it would be both over- and under-inclusive for the reasons given here. BLACK, JR., supra note 36 , at $33-36$. 
Problems of over and under-inclusiveness in the ordinary legal system can be addressed through sensible judgments by those who operate the system, particularly police, prosecutors, and judges. Impeachment regimes present a greater challenge in this regard because of the entirely legitimate role of the legislative branch, in which political interests and organized political parties play leading roles. Understanding an impeachment regime thus requires taking into account the actual functioning of political institutions, which is based on the alignment of political forces in the society, and attributes of specific parts of the regime may not track the performance of the regime as a whole. For example, even a regime such as Korea's that allows impeachment for a "violation of law" will not function in an overinclusive way unless the enforcement system allows it to do so. This is largely true in the ordinary legal system as well, with respect to which we are used to understanding the enforcement discretion of police and courts. What makes impeachment regimes unique is the roles that elected legislatures and political parties play in the enforcement process, especially in countries like the U.S., in which the judiciary's role is extremely limited. ${ }^{54}$ Returning to the discussion at America's Constitutional Convention, when Madison complained that allowing impeachment for "maladministration" would mean that the President would serve, in effect, at the pleasure of the Senate, Governeur Morris responded that the ground of maladministration "will not be put in force [and] can do no harm." 55 Morris appears to have intuitively accepted one of the points argued explicitly here, that an impeachment regime is a function both of the rules and of the enforcing institutions, though it might have been more persuasive had he explained why he believed the Senate could be trusted not to push "maladministration" to the extremes feared by Madison.

The issues that an impeachment regime can raise for a political system depends upon how the broader system is designed. With respect to

54. See BERGER, supra note 36, at 108-26 (arguing against total denial of judicial review in cases of impeachment); Vikram David Amar, Exactly What Are the Rules Concerning Supreme (or Other Federal) Court Review of Impeachment Proceedings?, VERDICT (May 13, 2019), https:// verdict.justia.com/2019/05/13/exactly-what-are-the-rules-concerning-supreme-or-other-federal-courtreview-of-impeachment-proceedings [https://perma.cc/VM8Z-NH3K]. Chief Justice Roberts's decisions in presiding over President Trump's impeachment trial in the Senate largely confirmed this stance, especially in his statement that he would not have cast a tie-breaking vote on a controversial procedural motion, an action that would have been very typical for a U.S. Vice-President presiding over ordinary Senate business. Jacqueline Thomsen, Roberts, Acknowledging He's 'Unelected,' Declares It 'Inappropriate' for Him to Break Tie in Impeachment Trial, LAW.COM: NAT'L L. J. (Jan. 31, 2020, 8:40 PM), https://www.law.com/nationallawjournal/2020/01/31/roberts-acknowledging-hes-unelected-declar es-it-inappropriate-for-him-to-break-tie-in-impeachment-trial/?slreturn=20210203231221 [https://perma .cc K7M2-CGNT].

55. BLACK, JR., supra note 36, at 28. 
presidential impeachment, the major issue in the U.S. is the balance of power between the two elected branches, the Presidency and Congress, as discussed by James Madison and Governeur Morris. ${ }^{56}$ In Korea, on the other hand, because the Constitutional Court serves as the adjudicating body in impeachment cases, the balance between all three branches is implicated. ${ }^{57}$ Despite these differences, one basic task of both impeachment regimes is the same: to set boundaries on the conduct of the countries' presidents. Both Korea and the U.S. rejected parliamentary systems, in favor of presidential systems, and over-inclusive impeachment regimes would undermine that model by subjecting the presidents to the supervision of the legislature (U.S.), or the legislature and the Constitutional Court (Korea). An underinclusive impeachment regime would also not be desirable because the possibility of impeachment must be high enough to deter misbehavior, or allow the peaceful removal of a duly elected president should the need arise. $^{58}$

While at first glance the problems of too much impeachment and too little appear symmetrical, the harms caused by too little impeachment may be more serious. In the case of a successful presidential impeachment, if the electorate feel that the impeachment was inappropriate they will be able to express their views in the next legislative election. In this way the democratic process itself, provided it is working properly, provides a selfcorrection mechanism if the legislature seeks to use impeachment against the president more than the citizenry thinks appropriate. The problems raised by an underutilized impeachment regime, by contrast, seem more of a threat to democratic governance, depending upon the powers granted to the president to act independently of the legislature. Even in a functioning democracy, a president, unconstrained by the threat of impeachment, may ignore the legal constraints on the office that separate democratic systems from authoritarian ones. A sitting president will have opportunities to use the powers of the office improperly, and a president who feels no threat of impeachment may abuse those powers to achieve reelection, fundamentally undermining the democratic process.

56. Cole \& Garvey supra note 5 .

57. See Daehanminkuk Hunbeob [Hunbeob] [Constitution] art. 111(1)2 (S. Kor.) (granting the Constitutional Court jurisdiction over impeachment trials).

58. Joseph Story, COMmentaries on the CONSTITUTION OF THE UNiTED STATES 273 (1833) ("[Impeachment] ought not to be a power so operative and instant, that it may intimidate a modest and conscientious statesman, or other functionary from accepting office; nor so weak and torpid, as to be capable of lulling offenders into a general security and indifference."). 


\section{COMPARING IMPEACHMENT CONTEXTS}

The central purpose of this essay is to facilitate comparison of impeachment regimes, rather than merely impeachment law. Impeachment regimes being defined to include legal rules, state institutions such as legislatures, and background social or political phenomena. The following sections address issues that help define the role of impeachment in a society.

\section{A. Who Can Be Impeached?}

An important vector along which regimes vary is the categories of officials subject to impeachment. When asking whether a particular type of official should be subject to impeachment, it will be helpful to consider what other disciplinary mechanisms might be available instead of, or as a supplement to, impeachment.

Neither the U.S. nor Korea limit impeachment to presidents. The U.S. Constitution allows impeachment of the "President, Vice President and all civil Officers of the United States," 59 including federal judges, who "hold their Offices during good Behaviour." ${ }^{60}$ The Korean Constitution allows impeachment of the "President, the Prime Minister, members of the State Council, heads of Executive Ministries, judges of the Constitution Court, judges, members of the Central Election Management Committee, members of the Board of Audit and Inspection, and other public officials designated by law." ${ }^{61}$ The U.S. approach is typical of the American Constitution in that it leaves important terms open to interpretation, while the Korean approach is more specific with respect to who can be impeached, and explicitly recognizes the possibility of further expansion through legislative action. The most interesting contrast between the U.S. and Korean approaches may not concern who can be impeached, but rather which institution, the legislature or the courts, makes that determination. ${ }^{62}$

The U.S. Constitution subjects "civil Officers" to impeachment, which means that Congress effectively expands the reach of impeachment whenever it creates a new officer position. The Korean Constitution also allows the legislature to expand the list of impeachable officials, but by its terms requires statutory designation. ${ }^{63}$ In the U.S., whether government employees are officers, and hence subject to impeachment, is often decided

59. U.S. CONST. art. II, $\S 4$.

60. Id. art. III, $\S 1$.

61. Daehanminkuk Hunbeob [Hunbeob] [COnstitution] art. 65(1) (S. Kor.).

62. See generally MARIE SEONG-HaK Kim, Constitutional Transition AND the Travail of Judges: The COURTS OF SOUTH Korea (2019) (recounting a history of judicial deference by South Korean courts to the legislature in matters of public policy).

63. DAEHANMinkuK HunBeob [HunBeOB] [CONSTItution] art. 65(1) (S. Kor.). 
ex post, by the federal courts hearing challenges to actions by those employees. ${ }^{64}$ If it is correct that the federal courts have no power to review impeachment decisions, it would seem to follow that an executive branch employee who might not qualify as an officer under the Supreme Court's Appointments Clause jurisprudence could be the target of an improper impeachment action. ${ }^{65}$ When the House impeached Senator William Blount in 1797, the Senate took the position that the action was inappropriate because Senators are not civil officers, ${ }^{66}$ but the decision that members of the legislature are not civil officers does not involve the same analysis as deciding whether a member of the executive branch is an officer. ${ }^{67}$ In a future case the House, and possibly the Senate, might be required to decide whether an official targeted with impeachment is an officer for purposes of the impeachment clause, and while common sense would suggest that they would be guided by Supreme Court precedent, without judicial review there would be no guarantee that they would be. A related consequence of the U.S. approach is that Congress should not be able to designate by statute that an official position will be an officer subject to impeachment unless it has also given that position the authority and autonomy required under Lucia and the Appointments Clause jurisprudence. If the federal courts are indeed unable to review impeachment decisions, preventing such an overreach by Congress could be difficult. ${ }^{68}$

64. Thus, cases determining whether specific U.S. officials are officers subject to impeachment are often brought under the Appointments Clause, U.S. CONST. art. II, § 2, cl. 2. See, e.g., Lucia v. SEC, 138 S. Ct. 2044, 2055 (2018) (finding that SEC administrative law judges are inferior officers, and therefore must be appointed in accordance with the Appointments Clause). See generally O.L.C., Officers of the United States, supra note 10 (describing the general process by which an office is deemed subject to the Appointments Clause and, subsequently, the privileges, protections, and restrictions that come with that office).

65. Members of Congress are sworn to uphold the Constitution. U.S. CONST. art. VI, cl. 3. Thus, they should follow Supreme Court precedent defining officer status under the Constitution. The caselaw is not extensive, however, leaving many official positions unaddressed as to whether they are subject to impeachment, and the cases tend to involve fact-specific inquiries into the exact powers Congress has given to the official in question. See, e.g., Lucia, $138 \mathrm{~S}$. Ct. at 2051-55 (elaborating on the Germaine and Buckley common law tests as a means through which the Court can determine whether individuals are "Officers of the United States").

66. AlEX SimPSON, A TREATISE ON FEDERAL IMPEACHMENTS 191-92 (1916).

67. Lucia and the Appointments Clause cases that precede it focus on the powers given to specific officials to exercise the authority of the federal government, and to what extent their exercises of that authority are subject to review by superiors. See Lucia, 138 S. Ct. at 2049. Individual members of Congress do not enjoy such powers, so the Lucia analysis would not be applicable.

68. The House has only used its authority to impeach officers below the President once; to deal with the corrupt Secretary of War William W. Belknap. KYVIG, supra note 11, at 30. Thus, its incentives with respect to creating officer positions are likely not guided by impeachability concerns. It is important to analyze the potentialities within impeachment regimes, however, because attitudes and behaviors can change. 
Turning to impeachment of judges, judicial independence is widely recognized as fundamental to the Rule of Law. ${ }^{69}$ Judges therefore must enjoy substantial job protection, not only from the executive and legislative branches, whom they must sometimes rule against, but also from the judiciary itself, as an organization. ${ }^{70}$ However, the benefits of judicial independence do not completely outweigh concerns about corruption or incompetence, so judges' job protection cannot be unlimited. ${ }^{71}$ Using the U.S. and Korean judiciaries to evaluate impeachment and judicial independence is appropriate because the U.S. judiciary is very thinly bureaucratized, ${ }^{72}$ while the Korean judiciary is highly bureaucratized, following Japanese and German practices. ${ }^{73}$ Bureaucratic organization facilitates discipline of judges by the judiciary, which might make judicial impeachment less necessary, but Korea also allows for judicial impeachment, even though its judges are appointed for fixed rather than lifetime terms. ${ }^{74}$ In addition to impeachment, the Korean Constitution allows for both criminal punishment and disciplinary action through the judicial bureaucracy, ${ }^{75}$ while the U.S. relies primarily on prosecution and

69. Norman S. Marsh, InT'L COMm'N OF Jurists, The Rule of LAW In A FreE Society: A REPORT ON THE INTERNATIONAL CONGRESS OF JURISTS, NEW DELHI, INDIA 279 (1959) (remarking that the rule of law is one of the fundamental attributes of a free society, but simultaneously noting that judges need not be absolutely independent from the legislature so long as the judge "observe[s] the law and the assumptions which underlie it, in the light of his own conscience, to the best of his abilities.") (emphasis added).

70. Judicial freedom from external pressures is necessary but not sufficient for the Rule of Law to function. Also necessary is that the judges use the insulation they enjoy to adjudicate according to the law, rather than indulging their personal preferences.

71. MARSH, supra note 69 , at 279-80.

72. Bureaucratized here means organized on a hierarchical, civil service model, in which judges generally begin their careers at the bottom of a single, pyramid-shaped bureaucracy through which they hope to rise over their careers. In bureaucratized judiciaries, judges are promoted to higher courts as they move up the bureaucracy, and the entire organization is controlled from the top. Judiciaries in the U.S., state and federal, are divided into different levels for purposes of appeals, and supreme courts play some role in organizing the courts beneath them, but the judiciaries themselves are not organized bureaucracies. See Patricia M. Wald, Commentary, Bureaucracy and the Courts, 92 YALE L.J 1478, 1479 ("[T] he courts hardly operate as a bureaucratic hierarchy. Vertically-district to circuit, circuit to Supreme Court-the federal judiciary does not function in the hierarchical fashion of a typical bureaucracy.").

73. On the history of the Korean judiciary, see generally DAE-KYU YOON, LAW AND POLITICAL AUTHORITY IN SOUTH KOREA 134, 149 (1990) (discussing the development of judicial independence through "the adoption of the Western democratic form of government" and judicial review within South Korea, while emphasizing the importance of political conditions on the judiciary's independence and review process); KIM, supra note 62 (highlighting the modern historical development of the Korean judiciary from the end of the Second World War to the present, and emphasizing the important influences Japanese and German legal traditions have had on the Korean judicial model).

74. The Korean Constitution provides that justices of the Supreme Court enjoy six-year terms, while ordinary judges enjoy ten-year terms. DAEHANMINKUK HUNBEOB [HUNBEOB] [CONSTITUTION] art. 105 (S. Kor.).

75. "No judge shall be removed from office except by impeachment or a sentence of imprisonment 
impeachment for serious judicial misconduct, supplemented by investigations of judges below the Supreme Court under the Judicial Councils Reform and Judicial Conduct and Disability Act of $1980 .^{76}$ In the U.S., impeachment has been used against judges far more often than against other officers. $^{77}$

In terms of over versus under-inclusion, the goal with respect to judges is that impeachment should be a rigorous yet smooth process when evidence of serious misconduct exists, but unavailable as a tool to punish unpopular judicial decisions. Neither Korea nor the U.S. have specific standards for judicial impeachments, ${ }^{78}$ but in neither country does it seem likely that overuse of judicial impeachment threatens judicial independence. In Korea, this is suggested by the legal structure, in which the Constitutional Court adjudicates impeachments, and would seem unlikely to allow impeachment to endanger judicial independence so long as Korea remains a democracy. The more likely threat to judicial independence arises from the bureaucratic nature of Korea's judiciary, which allows those at the top to exert substantial influence over the career paths of those below. ${ }^{79}$ In the U.S. there have been efforts to impeach judges on grounds best understood as political-for example, the effort to impeach Supreme Court Justice Samuel Chase in 1805, and Justices Earl Warren and William O. Douglas in the middle of the twentieth century. ${ }^{80}$ However, only the Chase effort made it as far as the

or heavier punishment, nor shall he be suspended from office, have his salary reduced or suffer any other unfavorable treatment except by disciplinary action." Id. art. 106. "The Supreme Court may establish, within the scope of law, regulations pertaining to judicial proceedings and internal discipline and regulations on administrative matters of the court." $I d$. art. 108.

76. 28 U.S.C. $\S \S 351-64$. For information on administration of the Act, see Judicial Conduct \& Disability, U.S. CTS., https://www.uscourts.gov/judges-judgeships/judicial-conduct-disability [https:// perma.cc/2EWQ-LDAY] (last visited Mar. 2, 2021).

77. See KYVIG, supra note 11 , at 395.

78. The Impeachment Clause does not specifically mention judges among those who can be impeached, but U.S. practice is that the judges are subject to the process. U.S. CONST. art. II, $\S 4$. Article III, Section 1 states that judges "shall hold their Offices during good Behaviour." Id. art. III, § 1. This suggests the possibility of a different standard for removal than "Treason, Bribery, or other high Crimes and Misdemeanors," but it has generally not been interpreted as setting a different standard for their removal through impeachment. Id. art. II, \$4; see CHARLES W. JOHNSON ET AL., U.S. HOUSE OF Representatives, House Practice: A Guide to the Rules, Precedents ANd Procedures of the HOUSE 608-13 (2017) ("The more modern view . . is that the "good Behaviour" clause more aptly describes judicial tenure; that is, the clause ... . merely means that Federal judges hold office for life unless they are removed under some other provision of the Constitution. Under this view, the power of removal together with the appropriate standard are contained solely in the impeachment clause."). For an extended discussion of judicial impeachments, including an argument that the standards should be different, see BERGER, supra note 36, at 127-88.

79. See Yoon, supra note 73, at 120-22.

80. KYVIG, supra note 11, at 1, 52, 106. 
Senate, where it was defeated. ${ }^{81}$ The vast majority of other judicial impeachments in the U.S. have involved clear misconduct rather than political differences. ${ }^{82}$ Although in comparison to South Korea's, the U.S. system may seem more susceptible to political abuse, that is unlikely to occur. So long as the two main political parties remain roughly balanced, the two-thirds supermajority requirement for conviction in the Senate should provide sufficient protection against judicial impeachments on political grounds.

Impeachment could also extend to members of the legislative branch. Legislators, too, need to be subject to removal for misbehavior, and in principle there is no reason impeachment could not provide one such method. ${ }^{83}$ The Korean Constitution leaves open impeachment of "other public officials designated by Act," and the National Assembly could enact the necessary statute allowing its members to be impeached, assuming they qualify as public officials. However, the Korean Constitution allows the National Assembly to discipline and expel its own members, ${ }^{84}$ so unless the National Assembly saw a concrete benefit to involving the Constitutional Court in disciplining National Assembly members, which impeachment would do, it is not clear why that body would enact the required statute.

Given the relevant Constitutional text, impeaching a U.S. legislator would require that legislators be "civil Officers of the United States," a problematic view despite the fact that the Constitution leaves "civil Officer" undefined. The Constitution speaks of officers and members of Congress as two distinct groups, suggesting that members of Congress are not officers. For example, in its requirement that "no Person holding any Office under the United States, shall be a Member of either House during his Continuance in Office." 85 If members of Congress were officers, and thus subject to

81. Valerie Strauss, Can a Supreme Court Justice Be Forcibly Removed from the Bench? A Quick Civics Lesson, WASH. PosT (Dec. 12, 2015, 11:27 AM), https://www.washingtonpost.com/news/answersheet/wp/2015/12/12/can-a-supreme-court-justice-be-forcibly-removed-from-the-bench-a-quick-civicslesson/ [https://perma.cc/3NFK-FM86].

82. See, e.g., KYVIG, supra note 11, at 9-34 (providing accounts of several historical judicial impeachments involving misconduct).

83. Raoul Berger's important study of the U.S. system includes an extended argument for why impeachment should be available against members of Congress. See BERGER, supra note 36, at 224-33. Berger's argument draws heavily on the English example, in which the House of Commons used impeachment against members of the House of Lords. Id.

84. "The National Assembly may review the qualifications of its members and may take disciplinary actions against [them]... . The concurrent vote of two thirds or more of the total members of the National Assembly shall be required for the expulsion of any member." DAEHANMINKUK HUNBEOB [HUNBEOB] [CONSTITUTION] art. 64(2)-(3) (S. Kor.).

85. U.S. CONST. art. I, $\S 6$, cl. 2 . 
impeachment, that requirement would be redundant. ${ }^{86}$ Furthermore, like Korea's National Assembly, the House and the Senate have the authority under the Constitution to expel their members on their own authority, without the involvement of the other house. ${ }^{87}$ That suggests that the Constitution's drafters did not envision impeachment being used to remove members of the legislature, since an easier path was available. It is also well established that members of Congress are not immune from the ordinary criminal process simply as a function of holding office, ${ }^{88}$ further reducing the need to have impeachment apply to them.

As noted above, impeachment of a legislator was attempted once in the early history of the U.S., when the House voted in 1797 to impeach Senator William Blount for corrupt and possibly treasonous dealings with Great Britain. $^{89}$ The Senate had already expelled Blount using its own Constitutional authority under Article I, Section 5, so the only practical effect of the House voting to impeach was that the Senate could impose the additional punishment of barring Blount from again holding high federal office. The Senate refused to act on the case, influenced by the fact that Blount was no longer in office, and thus arguably no longer subject to impeachment, and based on concerns that impeachment should not be available against legislators. ${ }^{90}$

\section{B. Impeachment in Relation to the Criminal and Civil Justice Systems}

In addition to addressing who may be impeached, countries must also address how their impeachment regimes interact with their ordinary civil and criminal justice systems. The issues are related, in part, because impeachment and the ordinary justice system, together with internal bureaucratic discipline, are the typical ways to discipline officials. If one is unavailable, it becomes important that others be available. For example, in terms of sanctioning wayward presidents, if impeachment is not available, the bad actors will not be subject to discipline by a bureaucracy, which makes it crucial that the ordinary justice system be able to reach them. As discussed above, judges who misbehave may be subject to sanction by the judicial

86. $C f$. Berger, supra note 36 , at 224-33 (recounting the historical developments that led to legislators being exempt from impeachment on the grounds that they are not "civil officers," but also criticizing this distinction).

87. U.S. CONST. art. I, $\S 5$, cl. 2 ("Each House may ... punish its Members for disorderly Behaviour, and, with the Concurrence of two thirds, expel a Member.").

88. A Sitting President's Amenability to Indictment and Criminal Prosecution, 24 Op. O.L.C. 222, 235 (2000) [hereinafter O.L.C., President's Amenability to Indictment].

89. KYVIG, supra note 11, at 22; BERGER, supra note 36, at 214.

90. KYVIG, supra note 11 , at 22. 
bureaucracy itself, ${ }^{91}$ lower executive branch officers may be subject to discipline by the president for misconduct even if not impeached or criminally prosecuted, and legislators may be subject to sanction and ultimately expulsion by the bodies in which they serve. Because presidents are not subject to these intra-branch sources of discipline, an important issue is how presidential impeachment relates to the criminal process ${ }^{92}$ though the civil justice system may be important as well. Two commonly discussed questions involve the effects of impeachment, if it occurs, and whether impeachment is the exclusive available means of sanction.

In setting the relationship between presidential impeachment and the ordinary criminal process, the Korean Constitution adopts one of the obvious options, stipulating: "The President shall not be charged with a criminal offense during his tenure of office except for insurrection or treason." ${ }^{.93}$ This immunity would seem to apply to acts committed either before or during the presidency, but also to clearly end upon removal from office through impeachment, ${ }^{94}$ thus providing a demarcation between the impeachment and criminal processes. The Korean Constitution does not address what steps might be taken to investigate a sitting president short of indictment, but prior to impeachment proceedings in the National Assembly, Korean prosecutors did officially identify President Park as a suspect and possible accomplice in their criminal investigation of her associate, Soon-sil Choi. ${ }^{95}$

The U.S. Constitution is less clear than the Korean Constitution in demarcating impeachment from criminal justice, providing only that "the Party convicted [by the Senate] shall nevertheless be liable and subject to Indictment, Trial, Judgment and Punishment, according to Law." 96 The text does not clearly indicate that the criminal process is unavailable until the person is removed by impeachment, only that impeachment and criminal

91. See, e.g., Daehanminkuk Hunbeob [Hunbeob] [Constitution] art. 106(1) (S. Kor.) (referencing the possibility of judicial discipline short of impeachment or criminal punishment, including suspension and salary reduction).

92. In the U.S. it is clearly established that judges, legislators, and executive branch officials below the President may be prosecuted while in office. O.L.C., President's Amenability to Indictment, supra note 88 , at $234-35$.

93. DAeHANMinKuK HunBeOB [HunBeOb] [CONSTitution] art. 84 (S. Kor.).

94. Id. art. 65(4) ("A decision on impeachment shall not extend further than removal from public office. However, it shall not exempt the person impeached from civil or criminal liability.") (emphasis added).

95. Sang-Hun, South Korea's Impeachment Process, supra note 23; Choe Sang-Hun, Park Geunhye Was Accomplice in Extortion, South Korean Prosecutors Say, N.Y. TIMES (Nov. 20, 2016), https://www.nytimes.com/2016/11/20/world/asia/park-geun-hye-south-korea-extortion-accompliceprosecutors.html [https://perma.cc/9N7T-C46B].

96. U.S. CONST. art. I, $\S 3$, cl. 7. 
liability are not mutually exclusive. ${ }^{97}$ The consensus position in the U.S., similar to in Korea, is that while a sitting president is not considered completely immune from the criminal process, he or she may not be indicted or prosecuted while in office. ${ }^{98}$ The President can be investigated for violations of federal law by specially-designated prosecutors, such as "special counsel" Robert Mueller, ${ }^{99}$ and the Supreme Court recently held that President Trump could not block a state grand jury subpoena duces tecum seeking financial documents, from before Trump took office, from his accounting firm. ${ }^{100}$ Although having access to special counsel investigation

97. See O.L.C., President's Amenability to Indictment, supra note 88, at 255 ("Recognizing an immunity from prosecution for a sitting President would not preclude such prosecution once the President's term is over or he is otherwise removed from office by resignation or impeachment.").

98. Id. at 260; Cass R. Sunstein, Opinion, A Sitting President Can't Be Prosecuted: Alexander Hamilton Helps Clarify the Constitutional Remedy, BLoOMBERG (July 31, 2017, 8:30 AM), https://www.bloomberg.com/view/articles/2017-07-31/a-sitting-president-can-t-be-prosecuted [https:// perma.cc/PTZ8-D3C5]; see also ANDREW COAN, PROSECUTING THE PRESIDENT: How SPECIAL Prosecutors Hold Presidents Accountable and Protect the Rule of Law 111-30 (2019). But see Ronald Rotunda, Opinion, The President Can Be Indicted-Just Not by Mueller, WASH. Post (July 27, 2017, 7:49 PM), https://www.washingtonpost.com/opinions/the-president-can-be-indicted-just-notby-mueller/2017/07/27/a597b922-721d-11e7-8f39-eeb7d3a2d304_story.html [https://perma.cc/749TWQB3] (arguing that a sitting president could be indicted, but also discussing the Department of Justice's position to the contrary); Jonathan Turley, Can Donald Trump Be Indicted While Serving as President?, WASH. POST (Feb. 27, 2018, 6:00 AM), https:/www.washingtonpost.com/news/posteverything/wp/ 2018/02/27/can-donald-trump-be-indicted-while-serving-as-president/ [https://perma.cc/8VL7-YMSV]. In this view, the function of the constitutional text in question is to make clear that criminal prosecution after impeachment will not constitute prohibited double jeopardy. O.L.C., President's Amenability to Indictment, supra note 88, at 222 (citing to Memorandum from Robert G. Dixon, Jr., Assistant Attorney Gen., Office of Legal Counsel, on Amenability of the President, Vice President and Other Civil Officers to Federal Criminal Prosecution While in Office (Sept. 24, 1973) (on file with U.S. Dep't of Justice)).

99. The current authority for the position of special counsels such as Mr. Mueller is found in 28 C.F.R. pt. 600 (2021), adopted by the Department of Justice to implement sections of the U.S. Code. For a lucid explanation of Mueller's status in relation to the President, see Richard J. Pierce, Jr., Opinion, The Easy Path to Firing Mueller, REG. REV. (Apr. 16, 2018), https://www.theregreview.org/ 2018/04/16/pierce-path-firing-mueller/ [https://perma.cc/43ZX-Q2VP] (explaining that the Attorney General can fire the special counsel for "good cause," and that the President can fire the Attorney General). The former independent counsel statute required independent counsels such as Ken Starr, who investigated President Clinton, to provide reports to Congress. 28 U.S.C. $§ 594(\mathrm{~h})$; Interview by Barak Goodman with Kenneth Starr, available at https:/www.pbs.org/wgbh/americanexperience/ features/clinton-interview-kenneth-starr/ [https://perma. cc/G5V9-EY9N] (last visited Mar. 29, 2021). The Justice Department's current special counsel regulations do not require this, and Attorney General William Barr gave Congress a redacted version of Mueller's report, while the Trump Administration and Congress sparred over other materials produced during the investigation. See David B. Rivkin Jr. \& Elizabeth Price Foley, Opinion, Congress Can't Outsource Impeachment, WaLl ST. J. (May 31, 2019, 6:20 PM), https://www.wsj.com/articles/congress-cant-outsource-impeachment-11559341259 [https:// perma.cc/2L4D-DFGP] (arguing that Democrats could not use Special Counsel Robert Mueller's probe to oust then-President Trump because doing so would violate separation of powers principles inherent in the American constitution).

100. Trump v. Vance, 140 S. Ct. 2412, 2431 (2020). Importantly, the President's lawyers conceded that he is not immune from a state criminal investigation while in office. $I d$. at 2426-27. The nature of 
materials may provide valuable assistance to Congress in its impeachment decision making, there are strong arguments in favor of the U.S. following the mandated Korean solution of impeachment first, then prosecution. As noted in the OLC opinion cited above, statutes of limitations can be tolled during a president's tenure in order to preserve the possibility of postpresidency prosecution, and because defending against a criminal prosecution could substantially distract a sitting president from carrying out her constitutional duties. ${ }^{101}$

Historically, there has been less focus in the U.S. on the relationship between the civil justice system and impeachment. But the decision by the Supreme Court in Clinton v. Jones, ${ }^{102}$ reversing the District Court, in part, and allowing Paula Jones' sexual harassment suit against Bill Clinton to proceed while he was President, was key to how that impeachment unfolded. The case has also opened the door to claims against Trump for prePresidential conduct. ${ }^{103}$ The District court initially ruled that President Clinton was immune from civil suit while in office, but allowed discovery, including the deposing of the President himself, to proceed while the presidential immunity issue was being appealed. ${ }^{104}$ This resulted in President Clinton being deposed about his relationship with Monika Lewinsky, and while under oath, he made statements about that relationship that arguably constituted the crime of perjury, substantially strengthening arguments for his impeachment. ${ }^{105}$ Given that precedent, President Trump's controversial past, and the extreme hostility toward him, it seems possible that the U.S. will have to work through these issues again if he wins reelection in November. Civil suits have been filed against him based on pre-election alleged conduct, ${ }^{106}$ and the President's foes may hope to corner him into repeating Clinton's mistakes of lying under oath or otherwise obstructing the judicial process. Many Republicans argued that Clinton's lies under oath justified his impeachment, despite objections that lying about extra-marital

U.S. federalism, with criminal law at both the state and the federal level, adds a level of complexity to this area that unitary systems like South Korea avoid.

101. O.L.C., President's Amenability to Indictment, supra note 88, at 222, 256.

102. Clinton v. Jones, 520 U.S. 681, 707-08 (1997).

103. Anna North, The Summer Zervos Sexual Assault Allegations and Lawsuit Against Donald Trump, Explained, Vox (Mar. 14, 2019, 3:09 PM), https://www.vox.com/policy-and-politics/2018/ 3/26/17151766/trump-lawsuit-summer-zervos-apprentice [https://perma.cc/F836-WCWE].

104. Clinton, 520 U.S. at 687.

105. POSNER, supra note 13, at 44-46. The two articles of impeachment adopted by the House were perjury and obstruction of justice, both arising out of the President's attempts to conceal his relationship with Lewinsky. Id. at 1.

106. Jennifer Peltz, AP Exclusive: Woman Who Says Trump Raped Her Seeks His DNA, ASSOCIATED PRESS, (Jan. 30, 2020), https://apnews.com/0475983f6c1e40628d2a3058e270a747 [https:// perma.cc/M3C7-5KE8]; North, supra note 103. 
affairs, even in a federal court deposition, should not be considered an impeachable offense. ${ }^{107}$ Especially if Democrats control both the House and the Senate after the 2020 elections, we could see the parties trade places on the issue. The better policy would probably be to stay civil litigation against a president until his or her term is over, as the District Court would have done in Paula Jones' suit against President Clinton, ${ }^{108}$ but the Supreme Court's decision in Clinton $v$. Jones denying such temporary immunity could be hard for a judge hearing a case against Trump to avoid. The Korean Constitution is also silent on the relationship between the civil justice system and impeachment, and the Korean courts have had less need than U.S. courts to rule on the issues that can arise. At least two group tort actions were brought against President Park based on actions she took while in office, one in January 2017, after she had been impeached by the National Assembly but before she was removed by the Constitutional Court, ${ }^{109}$ and one brought in June, 2017, after she had been removed. ${ }^{110}$ Both were dismissed at the trial court level, ${ }^{111}$ and the dismissal of the first suit has been upheld on appeal by the Seoul High Court. ${ }^{12}$ The suits were by large groups of citizens, each claiming small amounts for emotional damage due to Park's alleged misbehavior, and neither played a role in her impeachment. This suggests that civil litigation may become a regular part of the impeachment regime in Korea, as it now seems to be in the U.S., but so far that has not been the case.

\section{Impeachment for Official vs. Non-Official Conduct}

Impeachment regimes must also face the issue of whether impeachment should be available for conduct that did not occur during the performance of official duties. ${ }^{13}$ The argument for impeaching only on the basis of actions

107. POSNER, supra note 13 , at 207-08.

108. Clinton, 520 U.S. at 687.

109. Court Dismisses Citizens' Damage Suit Against Former President Park, YonHAP NEWS AGENCY (May 23, 2019, 5:08 PM) [hereinafter Court Dismisses Citizens' Damage Suit], http://yna.kr/AEN20190523007200315 [https://perma.cc/S76T-KU8R]; Anna Fifield, South Korean President Removed from Office over Corruption Scandal, WASH. Post (Mar. 10, 2017, 6:24 AM), https://www.washingtonpost.com/world/asia_pacific/south-korean-president-impeached-from-officeover-corruption-scandal/2017/03/09/23666a46-0488-11e7-a391-651727e77fc0_story.html [https://per ma.cc/CDM7-HHC5].

110. Court Rejects Second Damage Suit Against Former President Park, YonHAP NEWS AGENCY (Dec. 13, 2019, 1:54 PM), http://yna.kr/AEN20191213004400315 [https://perma.cc/Q5NP-WSGQ].

111. Id.; Court Dismisses Citizens'Damage Suit, supra note 109.

112. Appellate Court Rejects Citizens' Damage Suit Against Ousted Ex-President, YonHAP NEWS AGENCY (June 18, 2020, 5:26 PM), http://yna.kr/AEN20200618009800315 [https://perma.cc/J73PYHW3].

113. Objectionable conduct could occur at three different points in time: before taking office, while in office but not while performing official duties, and while in office and during the performance of official duties. 
taken in office makes sense if one sees impeachable officers as having separate public and private lives recognized and protected by the legal system. An ordinary public servant might be prohibited from engaging in certain activities at work, for example, but be free to engage in the same activities while off duty, or before taking the government position. Another approach could be that offenses could constitute grounds for dismissal if committed during job tenure, even if in a personal capacity, but not if committed before taking office. An impeachment regime could operate this way, establishing a structure for distinguishing among the many possible fact patterns that could arise, or could go to the opposite extreme of recognizing no distinction between being in or out of office, or between being on and being off duty. Officials in such an impeachment regime would be something like strictly at-will private employees, who may be dismissed for present or past conduct, whether on or off duty.

These issues are not directly addressed in the U.S. Constitution, either in the grounds for impeachment, or in other sections addressing the impeachment process. But these issues do come up in discussions of how the U.S. impeachment system should operate, ${ }^{114}$ and while it is typical to argue that limiting impeachment to acts committed during the performance of official duties would cause the regime to be underinclusive, that position must be combined with some kind of limiting principle to avoid overinclusion. The search for limiting principles can involve line drawing in terms of seriousness, time passed, or both. For example, in the American impeachment discourse, one could reasonably argue that minor misbehavior long before taking office definitely should not constitute grounds for impeachment, though both "minor" and "long before" are terms that could quickly become contested in any actual case. One need only think of the hostile behavior toward women that Donald Trump allegedly engaged in prior to his presidency to see the difficulty of applying this seemingly common-sense limiting principle in the heat of an actual impeachment discussion. With respect to bad acts while in office but not involving official duties, an argument offered against the Clinton impeachment was that his perjury occurred in a lawsuit arising out of private rather than official conduct, ${ }^{115}$ but that argument was also based on a view that his bad acts were

114. See, e.g., BERGER, supra note 36, at 202-23 (discussing impeachment in a historical context and instances where it was used to remove of judges for misbehavior); POSNER, supra note 13, at 104$05,171-73$.

115. KYVIG, supra note 11, at 394; Background and History of Impeachment: Hearing Before the Subcomm. on the Constitution of the H. Comm. on the Judiciary, 106th Cong. 90 (1998) [hereinafter Background and History of Impeachment] (statement of Cass R. Sunstein, Karl N. Llewellyn Distinguished Service Professor of Jurisprudence, University of Chicago School of Law) ("[A] false statement under oath is an appropriate basis for impeachment if and only if the false statement involved 
not that serious. ${ }^{116}$ Very bad acts, of which murder is a typical example, are often discussed as grounds for impeachment when committed. ${ }^{117}$

The Korean Constitution again opted for clarity by stipulating that officials may be impeached for offenses committed "in the performance of official duties." 118 The issue came up in the impeachment of President Noh, because the National Assembly had charged him with corruption for illegal activities during his presidential campaign. The Constitutional Court dismissed those claims for being based on conduct that did not take place in the performance of official duties. ${ }^{119}$ While on these issues the U.S. approach raises the danger of over-inclusion, the Korean position raises the danger of under-inclusion. Because the Korean Constitution stipulates that a president is immune from criminal prosecution while in office, ${ }^{120}$ if the applicable statute of limitations could not be tolled, a president who committed serious misconduct prior to taking office could escape both impeachment and prosecution. The preference in the Korean Constitution for clarity thus could come at the cost of effective accountability.

\section{Consequences of Impeachment}

The goal of an impeachment effort is typically thought to be removal from office, but the consequences need not be so limited. Therefore, it is worth comparing different approaches. In England, the main inspiration for the U.S. impeachment system, the House of Commons originally used impeachment to seek several sorts of criminal punishment, including "fines, property forfeiture, disqualification from future officeholding, imprisonment, or even execution," in addition to removal from office. ${ }^{121}$ Under the U.S. Constitution, impeachment "shall" result in removal from office, but the Senate also has the choice to impose "disqualification to hold and enjoy any Office of honor, Trust or Profit under the United States." ${ }^{122}$ If the Senate decides to add disqualification to removal from office, a separate

conduct that by itself raises serious questions about abuse of office.") (emphasis added).

116. Background and History of Impeachment, supra note 115, at 101 (statement of Arthur M. Schlesinger, Jr., Professor of History, Harvard University of Law) ("[L]ying about one's sex life is not a monstrous crime. ... Gentlemen always lie about their sex lives.").

117. POSNER, supra note 13, at 241 (referring to this as the "public acts + murder" approach to limiting impeachment's reach).

118. Daehanminkuk Hunbeob [Hunbeob] [COnStitution] art. 65(1) (S. Kor.).

119. Lee, supra note 15 , at 420 .

120. See Daehanminkuk Hunbeob [Hunbeob] [Constitution] art. 65(1) (S. Kor.).

121. KYVIG, supra note 11 , at 12 .

122. U.S. CONST. art. I, $\S 3$, cl. 7. Raoul Berger cites this possibility of future disqualification, beyond simple removal from office, in support of his argument that impeachment should be available against Senators. BERGER, supra note 36, at 225. 
vote requiring only an ordinary majority is done, not the two-thirds supermajority required for expulsion. ${ }^{123}$ The Korean Constitution adopts the less complicated alternative that the Constitutional Court's action in an impeachment can extend no further than removal from office. ${ }^{124}$ While the Korean approach is again less complex than the U.S., the additional sanction available to the Senate, though rarely used by that body, ${ }^{125}$ could be useful under certain circumstances. The fact that the Senate did not also disqualify impeached Judge Alcee Hastings from later holding high office allowed him to run for a seat in the House of Representatives, which he won in 1992, ${ }^{126}$ and still holds. The voters who elected Hastings afforded him a second chance at high office, and because the appointments of judges and principal officers in the executive branch must receive Senate confirmation, winning elected office, as Hastings did, would be the most likely path for an impeached official to regain high office. ${ }^{127}$ It may have been awkward for Hastings to assume a seat in the body that impeached him, but it would be hard to argue that his doing so seriously damaged the American political system. It is not hard to imagine a political system in which it could be harmful for impeached officials to be able to return to high office, however, especially for impeached presidents to run again for that office. ${ }^{128}$ If that were the case, the optimal impeachment regime might follow neither the Korean nor the U.S. approach, but instead make the ban automatic with removal.

Another issue related to the consequences of impeachment is how the removed official will be replaced, especially when that official is the head of

123. See KYviG, supra note 11, at 31 (discussing how the Senate's simple majority vote was sufficient to disqualify Court of Appeals Judge Robert W. Archbald from holding future office); GERHARDT, supra note 36, at 60 .

124. DAeHANMinkuk HunBeOb [HunBeOb] [CONSTitution] art. 65(4) (S. Kor.).

125. As of 1996 the Senate had imposed disqualification twice, in the cases of federal judges Archbald and Humphreys. See GERHARDT, supra note 36, at 60.

126. Id. at 60-62.

127. The Senate being the body that had convicted and removed that official in the impeachment. Id.

128. Brazilian President Dilma Rousseff was impeached and removed from office in 2016. Brazil's Former Leader Rousseff Fails in Bid for Senate Seat, EYEWITNESS NEWs [hereinafter Rousseff Fails in Bid for Senate Seat], https://ewn.co.za/2018/10/08/brazil-s-former-leader-rousseff-fails-in-bid-forsenate-seat [https://perma.cc/5PFD-UY3C] (last visited Mar. 14, 2021). Despite the fact that Brazil's Constitution bars impeached presidents from again holding public office, the Chief Justice of Brazil's Supreme Court ordered the Senate to hold a separate vote on whether to ban Rousseff from office for eight years, and imposed a two-thirds supermajority requirement. Matt Sandy, Dilma Rousseff's Impeachment is the Start of Brazil's Crisis-Not the End, TIME (Sept. 1, 2016, 2:29 PM), https://time.com/4476011/brazil-dilma-rousseff-crisis-impeachment/ [https://perma.cc/9BK4-DLF5]. That vote failed, leaving Rousseff free to seek office again. Rousseff ran unsuccessfully for a seat in the Brazilian Senate in 2018. Rousseff Fails in Bid for Senate Seat, supra note 128. 
state. When a Korean president is impeached and removed by the Constitutional Court, a new presidential election is held within sixty days from the date of the removal. ${ }^{129}$ This approach raises the possibility that impeachment will result in a shift in party control of the presidency, which happened in 2017 when left-leaning Moon Jae-In was elected to replace conservative Park Gun-Hye after she was impeached and removed. ${ }^{130}$ If one believes that impeachment efforts are unlikely to succeed absent a supportive electorate, it may seem reasonable that Korea's rule afforded liberal forces the opportunity to maintain their political momentum by trying to elect President Park's replacement in the election that immediately followed.

In the U.S., by contrast, an impeached president is simply replaced by the vice president, who serves out the remainder of the former president's term. ${ }^{131}$ This creates political dynamics quite different from those in Korea, and would be included in calculations by pro and anti-impeachment forces. During the impeachment effort against President Andrew Johnson, some Republican senators reportedly voted against removal because they were concerned about the consequences of their more radical Republican colleague, Benjamin Wade, taking Johnson's place. ${ }^{132}$ In the same vein, historian David Kyvig argues that sentiment to impeach Richard Nixon was tempered when the widely-disliked Spiro Agnew was his vice president, and that the fact that generally-respected Gerald Ford replaced Agnew made Nixon's impeachment more likely. ${ }^{133}$ Kyvig argues that in the Clinton impeachment, the fact that Al Gore was reasonably popular meant that he functioned more like Ford than like Agnew; he did not provide protection against impeachment for Clinton by being more objectionable himself. ${ }^{134}$ The Clinton-Gore pairing raises another important consequence of the U.S. system. The vice president who succeeds an impeached president may be a strong candidate in the next presidential election. If the Senate had convicted Bill Clinton in 1998, in all probability Gore would have run for president

129. DaehanminkuK Hunbeob [Hunbeob] [CONSTitution] art. 68(2) (S. Kor.).

130. Choe Sang-Hun, South Korea Elects Moon Jae-in, Who Backs Talks with North, as President, N.Y. TimeS (May 9, 2017) https://www.nytimes.com/2017/05/09/world/asia/south-korea-electionpresident-moon-jae-in.html [https://perma.cc/G9RL-2UB2].

131. U.S. CONST. amend. XXV, § 1 .

132. KYVIG, supra note 11, at 28-29. Johnson had no vice president, and at that time the President pro tempore of the Senate, Wade's position, was next in line to the presidency. The Man Whose Impeachment Vote Saved Andrew Johnson, NAT'L CONST. CTR. (May 16, 2020), https://constitutioncenter.org/blog/the-man-whose-impeachment-vote-saved-andrew-johnson [https:// perma.cc/ES5J-BG29].

133. KYVIG, supra note 11, at 399-400 (describing that a vice president who is generally disliked and viewed as "an unpalatable alternative to the president" may serve as a barrier towards the consideration of impeaching the sitting president, and is known as the "Agnew-Ford factor").

134. Id. at 400 . 
against George W. Bush in 2000, and would have done so from the advantageous position of being the incumbent. Kyvig argues that Gore probably would have defeated Bush in 2000, and if Clinton's removal had come late enough in the presidential term, then Gore might have been able to run for President again in 2004, entirely displacing the Bush presidency. ${ }^{135}$ This suggests that Republicans trying to impeach Clinton should have been careful about what they were seeking, but it also seems true that Democrats might have benefitted from a Clinton impeachment as compared to what history actually gave them, which was Bush defeating Gore in 2000.

Extending this analysis to the Trump impeachment effort, it seems unlikely that Vice President Pence served as a shield for Trump the way Agnew's personal flaws may have protected Nixon. With respect to the possible political effects of a successful Trump impeachment, there was concern among Trump opponents that a President Pence, running as the incumbent in 2020, might be difficult for Democrats to defeat. ${ }^{136}$ By the same token, if Joe Biden had defeated Trump in the 2020 election, Republicans might have regretted blocking conviction of Trump in the Senate.

Comparing the Korean and U.S. approaches to replacing an impeached president, the Korean model would seem to encourage impeachment efforts because the broad political groundswell necessary to bring about a successful impeachment could be expected to lead to victory in a subsequent replacement election, as happened in 2017. This should be encouraging to Korean politicians who think they might have the votes to push through an impeachment action in the National Assembly. Under the U.S. system, by contrast, the propensity to impeach presidents should be reduced by the fact that the results of a successful impeachment are less predictably positive for the party that spearheads the effort. The party that leads a successful presidential impeachment may hurt itself in the long term if the vice president who steps in becomes a strong contender in the next presidential election. The Democratic Party was able to take back the White House with Jimmy Carter's victory in the 1976 election, after having lead the impeachment effort that forced Nixon to resign in 1974, so there is no guarantee that a successful impeachment effort will backfire against the party that leads it. The danger of a successful impeachment backfiring certainly

135. See id. (citing U.S. CONST. amend. XXII, $\S 1$, allowing a person who becomes President through a replacement process and serves two years or less, to run for two additional terms as President).

136. See Bill Scher, How President Pence Would Blow Up 2020, Politico (Oct. 2, 2019), https://www.politico.com/magazine/story/2019/10/02/pence-trump-president-2020-228903 [https://per ma.cc/N7G9-7GBH]. 
seems higher in the U.S. than in Korea, however, which should have an effect on political calculations.

\section{IMPEACHMENT PROPER}

The factors discussed above are important for comparing impeachment regimes because they help determine when and how impeachment will be used, and its effects. To provide a more full comparison of impeachment regimes, however, it is also necessary to compare internal aspects of impeachment, such as the substantive standards, structures, and procedures that govern the process.

\section{A. Impeachment Standards}

The most obvious internal standard is the substantive grounds for impeachment, the impeachable offense, which has already been discussed at length. ${ }^{137}$ Ideally there would also be a clear evidentiary standard that would have to be met with respect to each alleged offense, in both the prosecuting and adjudicating body. Neither the Korean nor the U.S. constitution addresses these concerns, ${ }^{138}$ however, and in the U.S., where judicial review of impeachment decisions is considered unavailable, it is hard to see how evidentiary requirements could be enforced. That does not mean that putting evidentiary standards in the law would be meaningless, however, because like the definition of impeachable offense, an articulated evidentiary standard might influence legislators' decisions, even if it didn't fully constrain them. Evidentiary standards might also be used by the electorate, when its turn came to render its verdict.

The Korean system, in which the Constitutional Court sits as the adjudicating body, would seem much more capable of implementing evidentiary standards because that body is not simply a group of politicians. ${ }^{139}$ Assuming that courts are likely to be more constrained by evidentiary standards than legislative bodies are, in a system like Korea's, stipulated burdens of proof could be used to help ensure that impeachments are successful only when evidence of guilt is truly substantial. Korea's Constitutional Court has taken a judicial approach to its role in adjudicating

137. See supra notes 51-55 and accompanying text.

138. See GERHARDT, supra note 36, at 40-42, 112-13 (discussing the debate about adopting uniform rules of evidence and standard of proof in the Senate for impeachment trials); POSNER, supra note 13, at 120-21 (discussing the lack of a clear standard of proof in both the House and the Senate); Michael C. Dorf, The Articles of Impeachment, the Burden of Proof, and Propensity Evidence, DorF ON L. (Dec. 11, 2019), http://www.dorfonlaw.org/2019/12/the-articles-of-impeachment-burden-of.html [https://perma .cc/H7WM-54V9].

139. This assumption seems fair, even recognizing that judges are to some extent political actors and that legislators may well be trained as lawyers. 
impeachments, and in one scholar's view, "one of the consequences . . . is judicial development of a body of law that defines the terms of debate on the proper use of the impeachment device and binds future generations accordingly." 140

\section{B. Voting Requirements: Quorum and Voting}

Another set of issues crucial to impeachment regimes involves voting in the charging and the adjudicating bodies, in which both quorum and voting requirements potentially matter. The U.S. Constitution opted for the standard quorum requirement for impeachment votes in both the House and the Senate - a simple majority. ${ }^{141}$ Because the Constitution does not impose a supermajority requirement on impeachment voting in the House, allowing instead impeachment by a simple majority, ${ }^{142}$ the House could impeach on a low threshold, a simple majority vote of the simple majority necessary for a quorum. It is unlikely that members of the House would not attend an impeachment vote, however, so practically speaking the required vote is likely to be close to a majority of the full House membership. The Constitution set the requirement for conviction by the Senate at two-thirds of the senators present, ${ }^{143}$ which again is likely to be the full 100 senators. The drafters of the Constitution designed the Senate to be more deliberative and less subject to political passions than the House, ${ }^{144}$ and it is telling that for conviction they required a two-thirds supermajority of the body they thought would be more insulated from partisan politics. The drafters did not intend impeachment to be readily available. Furthermore, this was before the party system developed, which in their eyes would have increased the risk that impeachment would be used too readily. ${ }^{145}$ Evidence from Latin America suggests that presidential impeachment is more common where

140. Lee, supra note 15 , at 421 .

141. U.S. CONST. art. I, $\S 5$, cl. 1 .

142. Id. $\S 2$, cl. 5. (granting "the sole power of impeachment" to the House of Representatives).

143. Id. $\S 3$, cl. 6 .

144. See generally THE Federalist No. 62, at 457 (James Madison) (Floating Press 2011) ("The necessity of a senate is not less indicated by the propensity of all single and numerous assemblies to yield to the impulse of sudden and violent passions, and to be seduced by factious leaders into intemperate and pernicious resolutions.").

145. The Federalist No. 65, at 479-80 (Alexander Hamilton) (Floating Press 2011) ("The prosecution of [impeachments] . . . will seldom fail to agitate the passions of the whole community, and to divide it into parties more or less friendly or inimical to the accused. In many cases it will connect itself with the pre-existing factions, and will enlist all their animosities, partialities, influence, and interest on one side or on the other; and in such cases there will always be the greatest danger that the decision will be regulated more by the comparative strength of parties, than by the real demonstrations of innocence or guilt."). 
political parties are more fragmented ${ }^{146}$ so now that the U.S. has developed into a stable system of two parties with relatively equal representation in the Senate, conviction and removal is unlikely unless the case is extremely strong. Of the twenty cases in which the House has voted to impeach, the Senate has voted to acquit in eight, including all three impeached presidents. ${ }^{147}$ The only impeachments that have proceeded to conviction and removal by the Senate have involved lower court judges, and generally their wrongdoing has been clear. ${ }^{148}$

The Korean Constitution is similar to the U.S. with respect to voting at the first stage of impeachment, carried out by the 100 member National Assembly. For typical National Assembly actions, the Korean Constitution requires a simple majority to constitute a quorum, and a simple majority of those members present to take action. ${ }^{149}$ With respect to impeachment votes, however, Korea raised the bar in several ways. First, a motion to impeach must be brought by one-third of the members, in the case of non-presidential impeachments, and a majority of the members in the case of a presidential impeachment. ${ }^{150}$ This kind of procedural requirement does not exist in the U.S. Constitution, ${ }^{151}$ and would be up to the procedural rules of the House with respect to the role of committees in bringing forward motions to impeach. ${ }^{152}$ Assuming an impeachment motion is successfully brought, the votes required for approval again differ depending on who is being impeached, with a majority of the total National Assembly, not merely a majority of a quorum, required for a non-presidential impeachment, and twothirds of the total National Assembly required for a presidential

146. PÉREZ-LiÑÁN, supra note 20, at 156.

147. See List of Individuals Impeached, supra note 4.

148. Id.

149. DAeHANMinKuK HunBeOb [HunBeOb] [CONSTITUtion] art. 49 (S. Kor.).

150. DAehanminkuK HunBeob [HunBeob] [CONSTitution] art. 65(2) (S. Kor.).

151. The relevant provision simply states that "The House of Representatives shall . . . have the sole Power of Impeachment.” U.S. CONST. art. I, § 2, cl. 5.

152. The House has no generally applicable procedural rules governing impeachments. Brian Naylor, Fact Check: White House Legal Argument Against Impeachment Inquiry, NPR (Oct. 9, 2019, 1:52 PM), https://www.npr.org/2019/10/09/768540896/who-sets-the-rules-when-is-it-real-and-otherbig-questions-on-impeachment [https://perma.cc/FQ5N-78KG]. The procedural rules governing any specific impeachment must therefore be found in resolutions adopted by the House and by the relevant committees, most importantly the Committee on the Judiciary. See Elizabeth Rybicki \& Michael Greene, Cong. Rsch. Serv., R45769, The ImPeACHMENT Process IN the House OF RePresentatives 2-6 (2019). For the Trump impeachment, the key documents are House Resolution 660, adopted on October 31, 2019, which identifies the relevant committees and their responsibilities, and the "Impeachment Inquiry Procedures in the Committee on the Judiciary Pursuant to H. Res. 660," submitted for printing in the Congressional Record on October 29, 2019. H.R. Res. 660, 116th Cong. (2019); 165 Cong. Rec. E1357 (daily ed. Oct. 29, 2019). 
impeachment. ${ }^{153}$ The Korean Constitution thus formally establishes a twostage process at the National Assembly level through the separate motion requirement, whereas in the U.S. a similar result is normally accomplished by the House holding one vote to formally begin impeachment proceedings, subsequently voting on articles of impeachment to be presented to the Senate. ${ }^{154}$ Although the requirements for the two votes in the House are lower than the requirements for the two votes in Korea's National Assembly, especially with respect to presidential impeachments, the fact that the Korean party system is more fractured and fluid than the U.S. may reduce the constraining effect of Korea's higher voting threshold. ${ }^{155}$ The fact that the National Assembly impeached two presidents in the first thirty years of Korea's democratic constitution, while the U.S. House has impeached three presidents in 230 years, ${ }^{156}$ provides some support for this view.

Although voting in the first phase of the impeachment process is largely similar in the U.S. and Korea, voting in the second, adjudicatory, phase is substantially different. In Korea, an impeachment by the National Assembly moves for adjudication to the Constitutional Court, which consists of nine justices who normally rule by simple majority. For impeachment decisions, however, the Constitution requires a supermajority of six or more, ${ }^{157}$ which again would seem to be a high bar. In terms of voting requirements, the Korean system, like the U.S., thus seems designed to favor under-inclusion, possibly leaving someone in office for whom impeachment might seem appropriate to many. Nonetheless, the Korean constitution limits presidents to single five-year terms. ${ }^{158}$ So even if an impeachment fails, a president's critics will not be forced to tolerate his leadership too much longer. In the U.S., which has a two-term presidential limit, those who drove President Trump's impeachment could see him elected again. If they do, it will be

153. DAEHANMinKuK HunBeob [HunBeOB] [CONSTitution] art. 65(2) (S. Kor.).

154. See Molly E. Reynolds \& Margaret Taylor, What Powers Does a Formal Impeachment Inquiry Give the House?, LAWFARE (May 21, 2019, 1:57 PM), https://www.lawfareblog.com/what-powers-doesformal-impeachment-inquiry-give-house [https://perma.cc/P7VW-BVSG]. In the Trump impeachment, committees of the House began impeachment-related investigations before the full House voted on whether to begin an impeachment inquiry. Bryan Naylor, Impeachment Timeline: From Early Calls to a Full House Vote, NPR (Dec. 17, 2019, 5:00 AM), https://www.npr.org/2019/12/17/788397365/ impeachment-timeline-from-early-calls-to-a-full-house-vote [https://perma.cc/5GMK-RGEM]. This explains why the Judiciary Committee adopted procedural rules on September 9, 2019, several weeks before the full House voted to adopt Resolution 660, and why Resolution 660 directs various committees to "continue their ongoing investigations as part of the existing House of Representatives inquiry" into impeaching Trump. H.R. Res. 660.

155. Lee, supra note 15 , at 408-12 (discussing how the fragile political landscape and an alliance between opposition parties culminated in Roh's impeachment).

156. List of Individuals Impeached, supra note 4.

157. DAEHANMinKuK HunBeOB [HunBeob] [CONSTitution] art. 113(1) (S. Kor.).

158. DAEHANMINKUK HunBeOB [HunBeOB] [CONSTITUTION] art. 70 (S. Kor.). 
interesting to see whether they mount another impeachment campaign against him. There is no rule against it, and political passions in the U.S. show no sign of cooling.

\section{Structuring Impeachment Through Precedent}

Another important dimension on which internal impeachment mechanisms can vary is the extent to which decisions are constrained by precedent. A concern for precedent could arise with respect to major issues, such as the definition of an impeachable offense, but also many more technical issues, such as decisions concerning procedures in the charging and the adjudicating bodies. The U.S. impeachment regime does not display a strong commitment to precedent, ${ }^{159}$ whereas the Korean regime seems more committed. With respect to the definition of "high crimes and misdemeanors," there is no formal mechanism in the U.S. system by which future houses of Congress might be bound to follow the interpretations of earlier houses. Judicial review supports respect for precedent in the ordinary legal system, but the U.S. stance against judicial review of impeachments seems solid. The doctrine of stare decisis supports respect for precedent by ordinary courts even absent the possibility of review by higher courts, but the House and the Senate do not recognize stare decisis in impeachments. The procedural rules that the House and the Senate have adopted, discussed above, are also not judicially enforceable, though the Senate has at least enacted basic procedural rules that it leaves in place, while the House enacts procedural rules for each impeachment. By contrast, the Korean impeachment regime appears to allow a larger potential role for precedent to provide structure, largely because of the role of statutes, and the role of the Constitutional Court as the adjudicating body. ${ }^{160}$ In addition to the Constitution, the Constitutional Court Act also structures the Korean impeachment system, ${ }^{161}$ and that statute can be judicially enforced. The fact that the Constitutional Court adjudicates Korean impeachments also suggests that precedent plays some greater constraining role, though as with all high courts it is debatable to what extent precedent actually constrains that court's own decisions. It is attractive to think that vesting a court with the role of adjudicating impeachments may depoliticize decisions, but doing so could politicize the court, rather than depoliticizing impeachment decisions. Korea's Constitutional Court has struggled to appear as a court

159. See GERHARDT, supra note 36 , at $47-53$

160. Lee, supra note 15 , at 421 .

161. Hunbeob jaepanso beob [Constitutional Court Act] art. 2 (S. Kor.), translated in Korea Legislation Research Institute online database, https://elaw.klri.re.kr/eng_service/lawView.do? hseq=47509\&lang=ENG [https://perma.cc/WLS5-E3PJ]. 
when ruling on presidential impeachments, despite going out of its way to emphasize during the Noh impeachment that impeachment in Korea is a legal not a political process. ${ }^{162}$

\section{BROADER POLITICAL ENVIRONMENT}

The legal rules and institutions discussed above, both contextual and internal to impeachment, operate within national political systems that both determine and are determined by those legal structures. The law and the politics of impeachment are deeply intertwined, with the legal rules structuring the political maneuvering in the short term, but with political forces able to control at least some of the legal structures, especially those that are sub-constitutional, and therefore more easily changed. Individual countries will differ according to whether law or politics dominates at any given moment, but both matter for purposes of building a framework for comparison there is no point in asserting that one or the other predominates.

One of the most fundamental normative questions any presidential system must consider is how readily available presidential impeachment should be. Although there can be no right answer, some general considerations seem clear. In a stable, two-party system like the U.S., where legislators do not face term limits, neither individual legislators nor the dominant political parties would normally have a strong incentive to impeach a president. Members of both parties can easily imagine a president of their own party being subjected to the distraction of an impeachment attempt by a hostile House of Representatives. Although the supermajority requirement for conviction by the Senate makes conviction and removal very unlikely, allowing impeachment efforts to develop into a tit-for-tat pattern whenever different parties controlled the House and the presidency would make it hard for either party to enjoy a successful presidency unless it also controlled the House. Individual House members in competitive districts, concerned about reelection every two years, would also seem to have little incentive to pursue questionable impeachment cases. However, that would depend on whether they would benefit more from exciting their partisan supporters, or appealing to moderates who are likely to favor impeachment only in very clear cases. Legislators from relatively safe and highly partisan districts, on the other hand, might be more open to impeachment efforts, especially with respect to a president from an opposing political party.

The work of political scientists is especially helpful for understanding the wider political contexts within which impeachment regimes operate. Those who have engaged in comparative impeachment scholarship

162. See Lee, supra note 15 , at 423 . 
emphasize what Perez-Linan calls "legislative shields" that is, groups of legislators who oppose impeachment and are able to utilize the tools available within the relevant legal regime to block it. ${ }^{163}$ Building a legislative shield in Perez-Linan's sense will be easier for a president if the legal thresholds for impeachment are high, as in the case of the U.S. Senate, but it will also be easier if his or her party controls a significant number of seats in the legislature, and if many members of the opposite party are not sure they or their party will benefit from pursuing an impeachment. By this logic, presidents of countries with fragmented, multi-party systems, are more likely to be impeached, other things being equal, because they will have more trouble building effective legislative shields if they become unpopular. Small parties and individual politicians who may have voted with the president's party on particular issues will not be constrained from defecting by party discipline or by long-term, repeat-player interests, factors that weigh against impeachment in stable, two-party systems. ${ }^{164}$

Impeachment in Korea may be subject to this dynamic, as was noted with respect to the Noh impeachment, as Korea's parties tend to fragment, defect, and regroup fairly regularly. ${ }^{165}$ Whether that will result in impeachment being too common is a much more difficult question. Impeachment has become common in Latin America compared to other regions, but whether that represents a serious problem is contested. Some analysts characterize impeachment in Latin America as a functional substitute for the military coups that formerly plagued the region, ${ }^{166}$ and cast in that light, increasing resort to impeachment may represent progress. As Perez-Linan describes Latin America's evolution from coups to impeachments, "[a]s in previous decades, democratically elected governments continue to fall, but in contrast to previous decades, democratic

163. PÉREZ-LiÑÁN, supra note 20, at 132-33.

164. The recent impeachment crisis that led to President Kuczynski's resignation in Peru also demonstrates this dynamic. Kuczynski fended off the first impeachment attempt only by buying abstention in the impeachment vote from Congressman Kenji Fujimori and his allies, by pardoning Fujimori's father, ex-president Alberto Fujimori. Dube, supra note 14; The Short Unhappy Presidency of

Pedro Pablo Kuczynski, ECONOMIST (Mar. 22, 2018), https://www.economist.com/theamericas/2018/03/22/the-short-unhappy-presidency-of-pedro-pablo-kuczynski [https://perma.cc/WUB7 -RB4T]. According to an early report by The Economist, Peru's proportional representation system resulted in the party of Kuczynski's presidential opponent, Keiko Fujimori, receiving over half the seats in the legislature (73 of 130), despite receiving only $36 \%$ of the vote. Peru's President Pedro Pablo the Brief, ECONOMist (Mar. 28, 2018), https://www.economist.com/the-americas/2018/03/28/peruspresident-pedro-pablo-the-brief [https://perma.cc/HE67-A4NF]. According to this analysis, Peru's particular situation simply exacerbated a general tendency toward presidential impeachment in Latin American, that arises from combining the direct election of presidents with proportional representation for legislative elections. $I d$.

165. Lee, supra note 15 , at 409.

166. PÉREZ-LIÑÁN, supra note 20, at 3. 
regimes do not break down." ${ }^{167}$ Korea is on its fifth constitution since becoming fully independent in 1948, ${ }^{168}$ and between 1948 and 1987, when democracy was achieved and the current constitution enacted, the country suffered two military coups and a presidential assassination. ${ }^{169}$ Under the current constitution, Presidents Noh and Park have been impeached, and Park convicted and removed by the Constitutional Court, but the democratic regime itself has continued. The Korean impeachment regime may function in such a way as to make impeachment more common than it has been in the U.S., ${ }^{170}$ but if that helps stabilize Korea's democracy, Koreans may well approve.

\section{CONCLUSION}

The structure of this essay is based upon a few key characteristics of impeachment regimes, identified primarily by treating the U.S. and Korean systems as bases for ideal impeachment regime types, viewed through the familiar jurisprudential lens of over and under-inclusiveness. Some of those characteristics help determine the place of impeachment within the larger political system, while others are internal to the impeachment process itself. Ultimately, whether a given impeachment regime functions in a way that is over or under-inclusive is a political judgment for the citizens of that society to make, but systematic knowledge of how and why impeachment operates in other societies may help people better understand the merits and demerits of their own systems.

There is much more to be said about impeachment from a comparative perspective, but hopefully this essay will be useful to others interested in such inquiries. Unless we compare, we are limited to single-country studies, which don't allow one to say much about impeachment in general, a mechanism that is both available and important in many societies. Singlecountry studies also have the potential to mislead; what one might attribute to the legal rules in a country might actually be caused by the structure of its political parties, or some other extra-legal factor, and that would be apparent if a second country's impeachment regime had the same legal rules but functioned differently. In this way, comparative work can contribute to the

167. Id. (emphasis in the original).

168. Kim, supra note 62, at 3-4.

169. Id.

170. See Tae-jun Kang, Public Anger Swells in South Korea Over Coronavirus Outbreak, DIPLOMAT (Feb. 28, 2020), https://thediplomat.com/2020/02/public-anger-swells-in-south-korea-over-coronavirusoutbreak/ [https://perma.cc/NV6R-L6US] (noting that as of February 28, 2020, over one million Koreans had signed a petition demanding President Moon's impeachment over the government's handling of the COVID-19 outbreak). 
social scientific enterprise of identifying variables, formulating and testing hypotheses, and trying to understand causal forces behind the visible results. Such work has to take into account both legal and political factors, however, as impeachment regimes combine law and politics, both of which affect the regimes' ultimate functioning.

It is important at this point to return to a caveat offered at the beginning of this essay, which is that comparative scholarship will not answer ultimate questions about the meaning of an impeachment for a society, and that a more anthropological approach might be more appropriate if that is the question being asked. As the Trump impeachment has demonstrated in the U.S., and as the Noh and Park impeachments demonstrated in Korea, the meaning may well be as contested as the impeachment itself. What does it mean that in the Trump impeachment the House and Senate both voted on nearly perfectly partisan lines, the first to impeach and the second to acquit? Does it mean that the Republican party debased itself by not standing up to Trump's bombast and removing him from office? Or, is the meaning of this impeachment episode that the Democrats in the House did such a poor job of investigating Trump and putting together articles of impeachment that the Republicans acted appropriately in summarily rejecting the case in the Senate? Americans remained divided on such issues after the Trump impeachment process had ended, ${ }^{171}$ and Korean public opinion remained divided after the Park impeachment as well. ${ }^{172}$

As wrenching for a society as an impeachment can be, especially impeachment of a president, it is crucial for democracy that the possibility of impeachment exist. For the possibility to exist, there must be rules and processes to carry it out, and the goal of this paper has been to bring key rules and processes to the surface for examination. Many choices go into the construction and operation of an impeachment regime, and if those choices and their normative implications are more clearly understood, perhaps impeachment will become more of the not-too-much-not-too-little good that democratic societies need it to be.

171. John Gramlich, Looking Back on Impeachment, a Quarter of Americans Say Trump Did Nothing Wrong, PEw RSCH. CTR. (Mar. 17, 2020), https://www.pewresearch.org/fact-tank/2020/03/17/ looking-back-on-impeachment-a-quarter-of-americans-say-trump-did-nothing-wrong/ [https://perma.cc/ 2GSW-BHY6].

172. Yong Suk Lee, Social Media and Rigid Beliefs: Evidence from Impeachment of the President 5-6 (Stanford Ctr. on Glob. Poverty \& Dev., Working Paper No. 1021, 2018). 